\title{
ROTSTEKENINGEN VAN CURAÇAO, ARUBA EN BONAIRE
}

\author{
DOOR
}

\section{P. WAGENAAR HUMmelinck}

met medewerking van A. D. RINGMA

Als wij nagaan wat is overgebleven van hen die vóór de komst van de veroveraars uit de Oude Wereld de Benedenwindse Eilanden bewoonden, dan treft ons een groot gemis aan feitelijke gegevens, buiten het weinige dat door geschiedschrijvers is opgetekend.

\section{Het oudheidkundig onderzoek.}

Er was tijd, waarin er op de eilanden een priester rondzwierf die ,schatten" verzamelde. In die jaren, 1870-1886, was er nog heel wat meer van de oude Indiaanse bewoners te vinden dan thans, en pastoor A. J. van KoolwIJK had niet alleen een grote belangstelling, en een fijne neus voor het vinden van oudheden, maar was bovendien zo verstandig, dat hij begreep dat hij - met zijn totaal gemis aan wetenschappelijke vorming in deze richting - zijn liefhebberij niet op eigen gelegenheid moest botvieren, maar zich hierbij onder leiding moest stellen van iemand die van deze zaken meer op de hoogte moest worden geacht dan hijzelve. De Indianen-Caraïben, oorspronkelijke bewoners van Curaçao (1881) en De Indianen Caraiben van het eiland Aruba (1882) waren onderwerpen welke hem voortdurend bezig hielden ${ }^{1}$ ).

Al kunnen wij het betreuren - diep betreuren zelfs — dat men in het moederland toentertijd niet wat meer belangstelling voor zijn nasporingen had - waardoor stellig vele waardevolle gegevens

1) Wij weten thans dat deze oorspronkelijke bewoners geen Caraïben waren, maar Arowakken, behorende tot de Caquetio - of misschien zelfs tot een bepaalde groep welke ,,indios Curaçaos” werden genoemd. 
zijn verloren gegaan - een geluk blijft het, dat, door zijn relatie met de directeur van het Rijksmuseum van Oudheden, vaN KoolwiJK's verzamelingen zijn bewaard gebleven en thans nog in het Rijksmuseum voor Volkenkunde te Leiden kunnen worden bestudeerd.

Reeds in September 1879 werd door deze directeur, dr C. LEEMANS, een groot deel van het tot op dien datum bij hem binnengekomen materiaal in een lijst van Antiquités américaines ..... à Leide (1880) beschreven en afgebeeld. Dat men in wetenschappelijke kringen de waarde van vaN KooLwiJk's werk wel degelijk inzag, blijkt voorts uit de Beiträge zur Anthropologie, Etnographie und Archaeologie Niederl. Westindiens (1904), waarin drie geleerden publiceerden over zijn verzameling, korte tijd nadat het laatste deel hiervan in het bezit van het Museum was overgegaan $\left.{ }^{1}\right)$. Het blijkt ook uit de uitvoerige en rijk geillustreerde beschrijving van de archaeologische voorwerpen van The praecolumbian and early postcolumbian aboriginal population of Aruba, Curaçao, and Bonaire welke J. P. B. DE JossELIN DE JoNG, in 1918, het licht deed zien.

Van het oorspronkelijke plan van deze laatste onderzoeker om in volgende artikelen ook nog de rotstekeningen te behandelen, alsmede het materiaal op taalkundig en volkenkundig gebied dat in de literatuur te vinden was - is niet veel gekomen, niet het minst door het ontbreken van voldoende gegevens. Hij schonk ons in 1920 nog een voortreffelijk overzicht van De betekenis van het archaelogisch onderzoek op Aruba, Curaçao en Bonaire, en vergeleek in 1923 de urnbegravingsmethoden van de eilanden met die welke elders in Amerika worden gevonden - maar dit bleek dan toch tevens het einde te betekenen van het wetenschappelijk oudheidkundig onderzoek van onze Benedenwinden, waaraan toch een zo grote behoefte bestond ${ }^{2}$ ).

De groeiende belangstelling voor het prae-historisch onderzoek van de Nederlandse Antillen in de laatste jaren uit zich vooralsnog slechts in een toenemend aantal beschouwingen in plaatselijke bladen, die hun ontstaan eerder danken aan een behoefte

1) Het Rijksmuseum voor Volkenkunde bezit van van KoolwiJ K vier collecties, resp. uit 1883, 1885, 1886 en 1887.

2) In 1947 publiceerde prof. DE JossELIN DE JoNG, in de,,Mededelingen van het Rijksmuseum voor Volkenkunde", $\mathrm{nr}$ 1, nog een beschrijving van het Archeological material from Saba and St. Eustatius, dat door hem in 1923 op een expeditie met Denen was verzameld. 
tot het geven van een eigen voorstelling van zaken naar bekende bronnen, dan aan het op wetenschappelijke wijze verwerken van nieuwe feiten, welke onze kennis van de vroegere Indiaanse bevolking zouden kunnen vermeerderen.

Dat de leden van de ,Natuurwetenschappelijke Werkgroep Nederlandse Antillen" zich tot archaeologisch veldwerk voelden aangetrokken, ligt voor de hand. Rotstekeningen, schelphopen en potscherven zijn nu eenmaal tè opvallende zaken, dan dat personen die in de natuur belangstellen hieraan zouden kunnen voorbijgaan.

Hoe komt het toch, dat er van Curaçao geen rotstekeningen bekend zijn, terwijl zij op Aruba en Bonaire in een zo grote getale en in een zo fraaie uitvoering zijn te vinden? - was de vraag welke zich daarbij op de voorgrond drong. De enige aannemelijke verklaring welke voor dit verschijnsel kon worden gegeven was, dat deze tekeningen op Curaçao zouden zijn gemaakt op plaatsen waar ze minder goed bewaard konden blijven. In dat geval mocht worden verondersteld, dat bij goed zoeken nog wel iets van deze rotsschilderingen zou worden teruggevonden.

Een van de leden van de "Werkgroep" - de heer A. D. RinGMA - die op zijn zwerftochten over het eiland een opmerkelijke voorliefde voor het onderzoek van grotten aan de dag had gelegd, besloot daarop in het bijzonder op Indiaanse overblijfselen te gaan letten. Vele excursies werden tot dit doel — van Maart 1949 tot Juni 1951 - door hem gemaakt; in de eerste tijd dikwijls met de schrijver van dit overzicht tezamen, soms ook in gezelschap van andere leden van de ,Werkgroep”, maar meestal toch alléén - in de uren dat zijn tegenwoordigheid in de verkeerstoren van het Vliegveld Hato niet noodzakelijk was. En met verrassende resultaten!

Een mededeling, dat vroeger bij de Tafelberg van Santa Barbara tekeningen waren gevonden, kon spoedig worden bevestigd. Hierna werd een gerucht gevolgd, dat leidde tot de ontdekking van de schilderingen van de Seroe di Cueba op Savonet. Daarna begon Ringma aan een systematisch onderzoek van de noordkust, waarbij hier en daar opgravingen werden gedaan. Rotstekeningen bleken op verscheidene plaatsen voor te komen op één plaats zelfs inscripties! Afvalhopen werden aangetroffen, potscherven verzameld en skeletten gevonden. Ook Aruba werd onderzocht, maar niet grondig genoeg om een bevredigend overzicht te krijgen van de vele belangwekkende zaken welke op dit eiland te vinden zijn. Ook Bonaire kon niet die aandacht ge- 
geven worden welke dit eiland, vanwege zijn interessante rotsschilderingen, verdient. Het leek daarom verstandig om met de beschrijving van de talrijke en mooie tekeningen in de Grot van Fontein op Aruba en van de bekende vindplaatsen van Onima en Spelonk op Bonaire te wachten, tot over voldoende materiaal kan worden beschikt om een goed overzicht te kunnen geven. Het ligt in de bedoeling dat bij die gelegenheid ook nog iets naders over de betekenis en de techniek wordt gezegd, en enkele vergelijkingen worden getrokken met rotstekeningen welke elders worden aangetroffen.

Over hetgeen bij deze nasporingen nog verder werd gevonden zal, naar wij hopen, ter zijner tijd nog iets kunnen worden medegedeeld.

Ringma heeft gestreefd naar een inventarisatie van de rotstekeningen op de vindplaatsen welke hij bezocht. De serie schetsen, door hem in het veld gemaakt - door de schrijver aangevuld voor wat betreft enkele vindplaatsen welke niet door hem werden bezocht - vormt de basis van deze verhandeling.

Daar het in vele gevallen zeer moeilijk bleek een objectief beeld te krijgen van hetgeen nog van de rotsschilderingen is overgebleven, werden tevens nog enkele schetsen opgenomen, door de schrijver in het veld gemaakt, welke voor een deel aan de hand van foto's werden bijgewerkt. En tenslotte vinden wij in dit artikel nog een aantal foto's zelve.

Moge de aanschouwing van het materiaal, dat in deze eerste publicatie over oudheidkundige vondsten van leden van de ,Natuurwetenschappelijke Werkgroep Nederlandse Antillen" zonder commentaar wordt aangeboden - in samenhang met de bestudering van nog andere overblijfselen van deze verdwenen cultuur - ons iets nader kunnen brengen tot de ons nog zo weinig bekende vroegere bevolking van de Benedenwindse Eilanden!

\section{Wat ons bekend is van de rotstekeningen.}

De eerste beschrijving van rotstekeningen op de Benedenwindse Eilanden danken wij aan Dominé Bosch (1836, p. 219-220). Hij bezocht de mooiste en rijkste vindplaats: de grot van Fontein op Aruba, en zegt hierover (letterlijk), ,, Aan de wanden der grot... zijn talrijke figuren... De hand, die ze hier neêrschreef, was die van een' geoefende; de regte lijnen en hoeken en de zuivere omtrekken dier figuren doen zien, dat zij niet gemaakt zijn op de wijze, waarmede iemand, die niet schrijven kan, gewoon / is een merk te maken, dat voor zijn naamteekening moet dienen; zij schijnen door hare eenzelvigheid de aanteekeningen geweest te zijn 


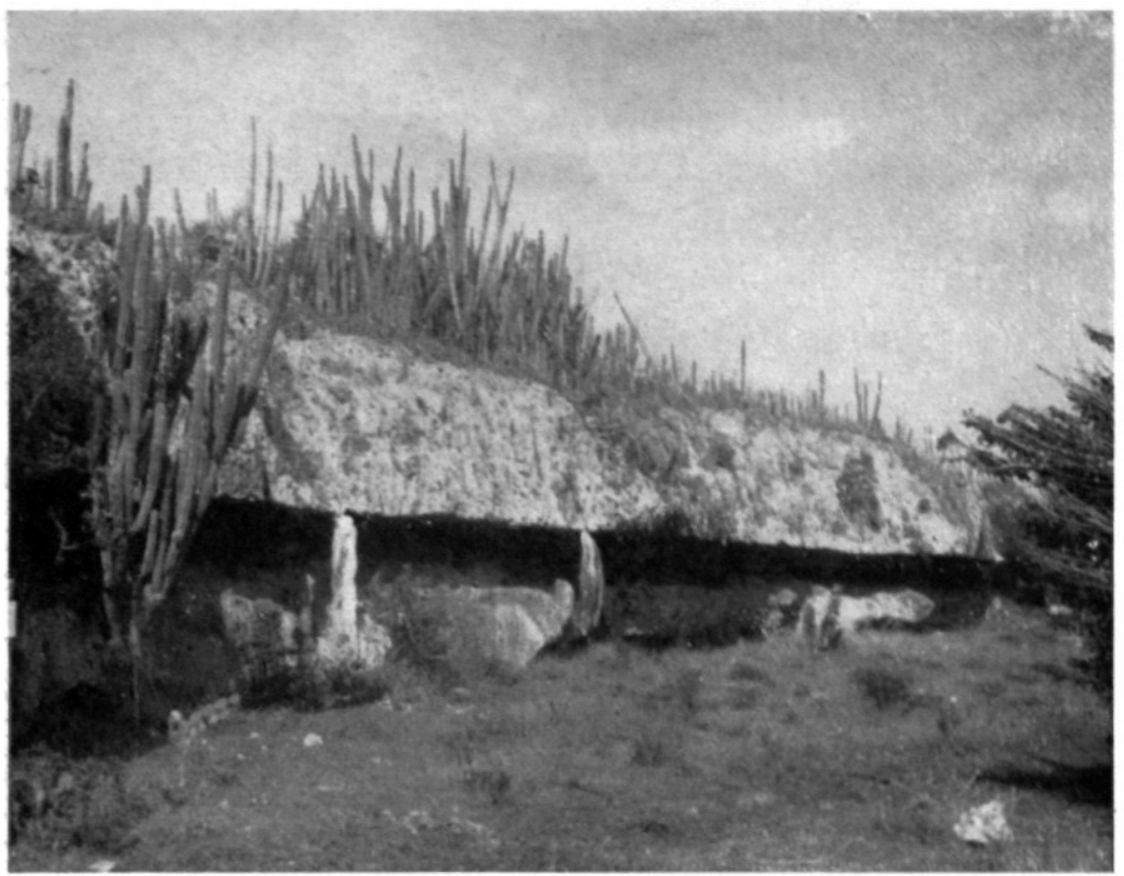

Fig. 1. Oude brandingsnis in de steile rand van het middenterras van Hato (iets oostelijk van C 7). In dergelijke brandingsnissen aan de noordkust van Curafao bevinden zich de resten van een groot aantal tekeningen (vgl. fig. 6-8). Fig. 1. Fossil surf notch at Hato (East of C 7). - Several linear designs are found on the roof of the same kind of rock shelter along the northern coast of Curaçao (cf. fig. 6-8).

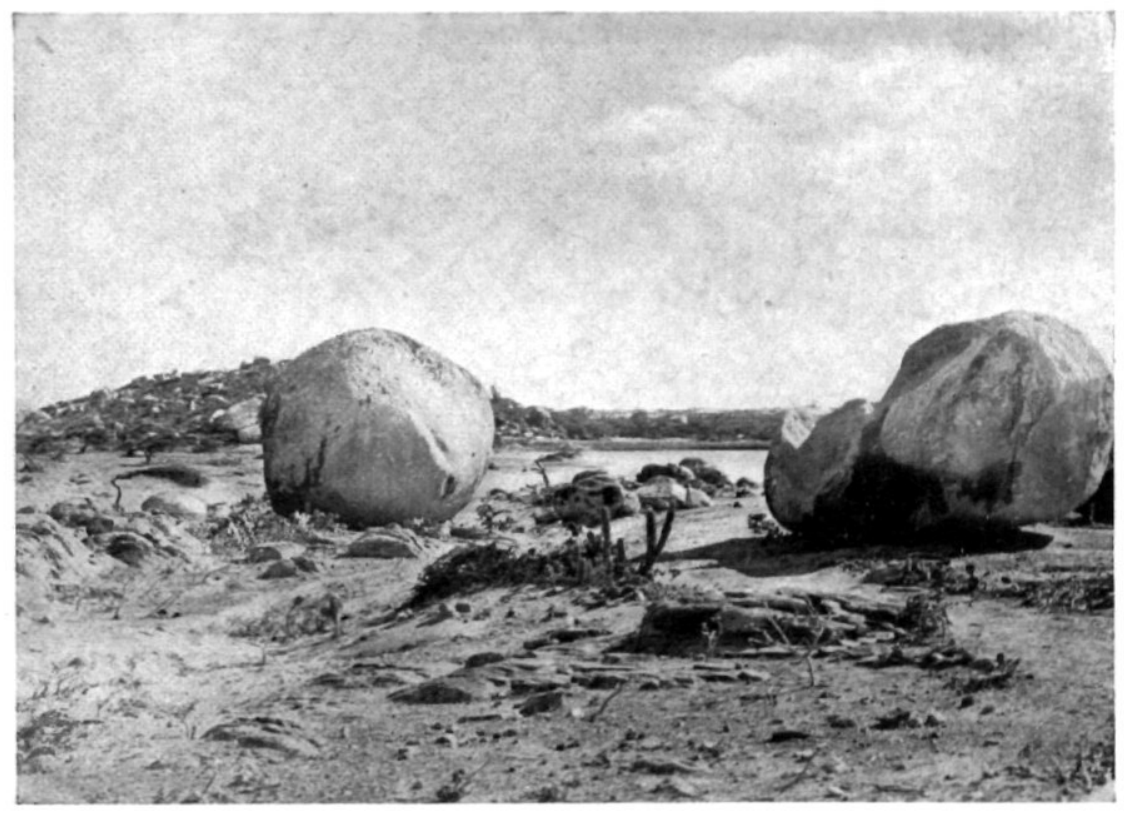

Fig. 2. Grote, afgeronde diorietblokken in de omgeving van Santa Cruz (iets zuidoostelijk van A 3 , naar het Zuiden toe gezien). - Vele monoliethen van West Aruba vertonen grote uithollingen waarin soms gekleurde tekeningen zijn aangebracht (b.v. die van A 2 en A 3).

Fig. 2. Large boulders of diorite near Santa Cruz (Southeast of Z 3, looking southward). - Many of these boulders in Western Aruba show big round cavities with whitish and brownish designs (as in $A 2$ and A 3). 


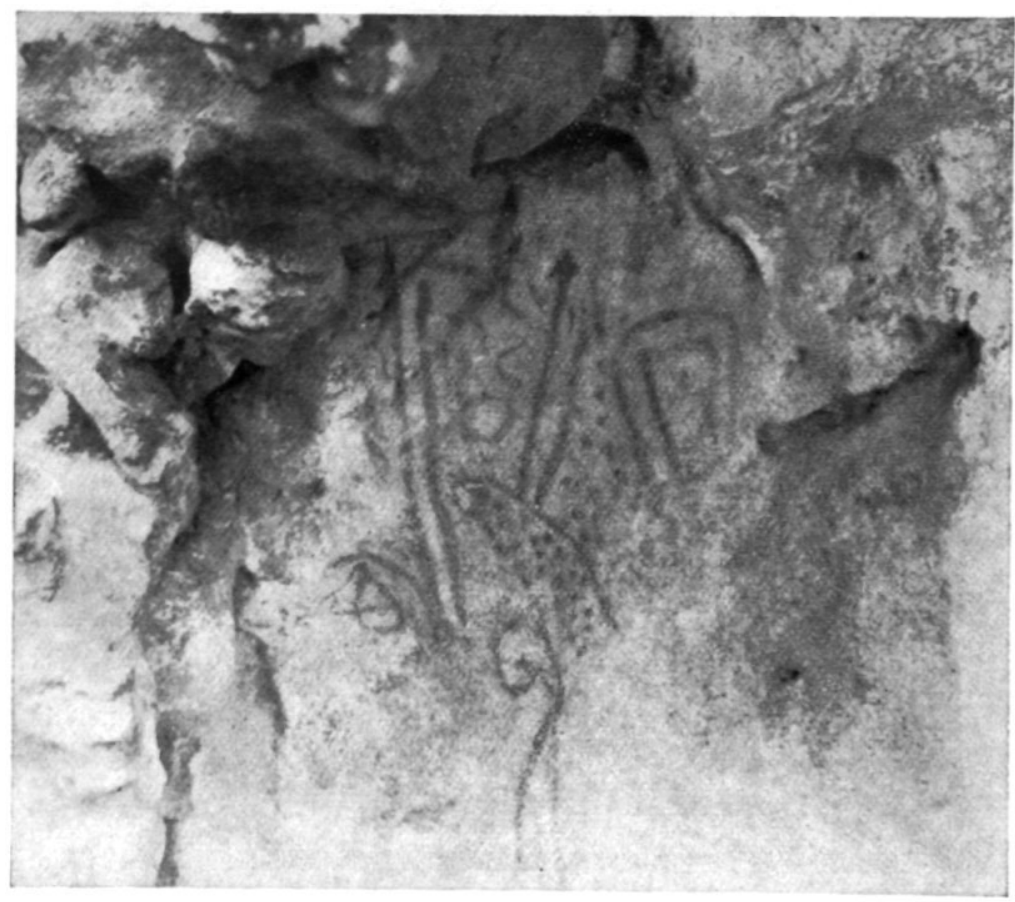

Fig. 9. Resten van tekeningen op een, door oude druipsteen beschut gedeelte van de noordoostelijke kalksteenwand van de Tafelberg op Santa Barbara, Curaçao (C 1a; vgl. fig. 16-17).

Fig. 9. Petrographs in red of the Tafelberg of Santa Barbara, Curaf̧ao (C $1 a$; cf. fig. 16-17).

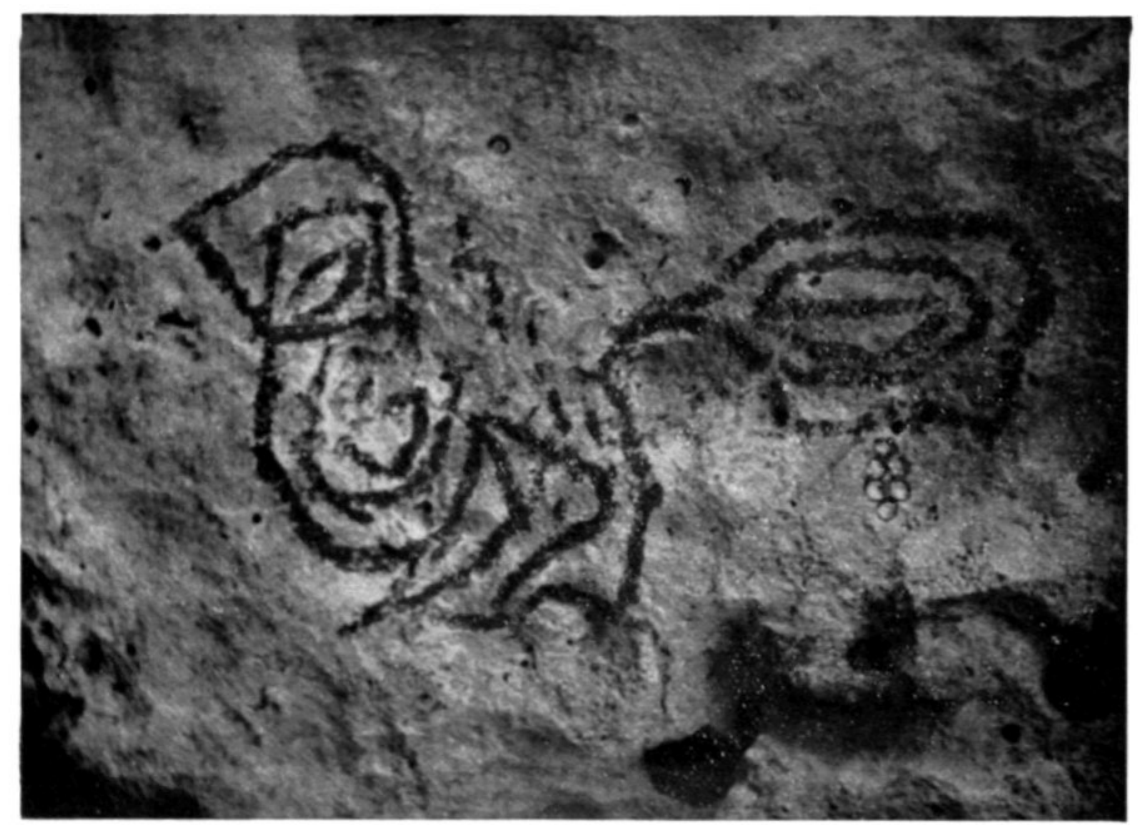

Fig. 10. De op een vogel gelijkende rotstekening van de Seroe di Cueba, Curaçao (C $10 n$; vgl. fig. $22-24$; foto van J. G. DE JoNG).

Fig. 10. Curą̧ao rock drawing called "the bird" (C 10n; cf. fig. 22-24). 
van het verloop des tijds, of van gebeurtenissen, welke in het huiselijk of openbaar leven der oude Indianen plaats vonden. Derzelver kleur is van eene donker roode of bruine verfstof, waarschijnlijk den oker, die, volgens de mededeeling der ingezetenen, geene de minste verandering heeft ondergaan, van dat de eerste Europesche bezoekers dezelve opmerkten. Later heb ik vernomen, dat er in andere hier nabij gelegene .... grotten .... en misschien ook in de grot, waarin ik geweest ben, een volkomen beeldschrift (Hieroglyphen) gevonden wordt, bestaande uit de teekenen van het uitspansel, uit gedaanten van dieren en andere voorwerpen. Er zijn daarvan verscheidene naauwkeurige afteekeningen gemaakt, welke ik echter niet kon ter hand krijgen, toen ik dezelve noodig had. Intusschen is het aanwezen van dit beeldschrift .... in de grotten van $A r u b a$ zeer opmerkelijk, dewijl het verscheidene denkbeelden en vragen ons voor den geest brengt, en doet zien, dat de eens hier wonende Indianen eene hoogere mate van beschaving bezaten dan wij, zonder het aanwezen dier Hieroglyphen, zouden vermoed hebben."

TEENSTRA (1837, p. 200) vermeldt slechts de aanwezigheid van ,,donkerroode figuren (hieroglyphen)" op de wanden van onderaardse spelonken in de kalksteenrotsen van de Arubaanse noordkust.

VAN KoolwiJK (1882, p. 225-226) geeft over de Arubaanse ,opschriften" talrijke bijzonderheden. De grote zorg, waarmede de figuren vervaardigd zijn, doet hem, evenals Bosch, ,, vooronderstellen dat ze, gelijk de hiëroglyphen der Egyptenaren, een beeld- of letterschrift, of beide te zamen vertegenwoordigen." / ,De grotten, waarin die opschriften gevonden worden zijn of in kalkrotsen of onder granietblokken. Tot de eerste soort behooren de grotten van Fontein en Carachito. De eerste is eene grot met ruimen, hoog gewelfden ingang.... De indiaansche opschriften bevinden zich tegen het gewelf, ter plaatse waar het daglicht ze duidelijk doet voorkomen. .... De grot van Carachito .... is tusschen struikgewas en rotsblokken verborgen en moeielijk te genaken, ook is zij te klein om tot eene geschikte woonplaats te dienen. .... eene hooger gelegene grot .... is slechts met eene vrij hooge ladder te bereiken .... Opschriften .... zijn er niet aanwezig. Eene derde grot .... is ten Oosten van de grot gelegen en bevat eenige opschriften. .... De tweede soort van grotten zijn met den beganen grond gelijk en bevinden zich onder granietblokken. .... Dat eenigen dier grotten den Indianen huisvesting verleend hebben, blijkt uit de nog bij het volk bestaande overlevering en uit de omstandigheid, dat ik in sommige fragmenten van indiaansche potten heb gevonden. .... Alle indiaansche opschriften zijn met zorg en met eene vastehand aangebracht en hebben ongetwijfeld zekere betekenissen.... Zooverre ik heb kunnen opsporen zouden, volgens traditie, eenige figuren onder granietblokken de vorige eigenaars of bewoners dier plaatsen aanduiden. De verven, waarmede die figuren aangebracht zijn, hebben over het algemeen eene frissche kleur. De roode en de bruine verf komen het meeste voor, ook de witte is niet zeldzaam; de zwarte datarentegen, die doorgaans de indiaansche potten kleurt, heb ik bij opschriften slechts twee maal aangetroffen. Ik maak hieruit op, dat ook de kleur der verf eene betekenis heeft en zoo zoude de bruine en roode verf betrekking kunnen hebben op de handelingen der Indianen, de witte op die der blanken en de zwarte op die der Afrikanen." Volgens van KooLwiJK $(1885$, p. 183) - in het omvangrijke geschrift 

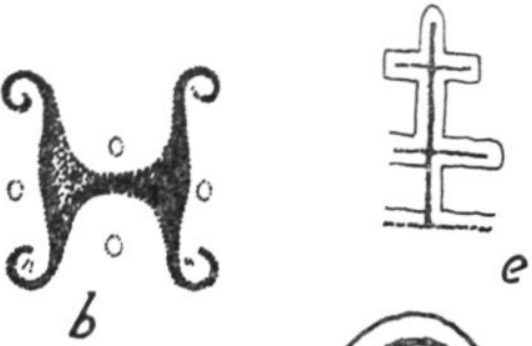

e<smiles>CC(C)(C)C</smiles>

$g$
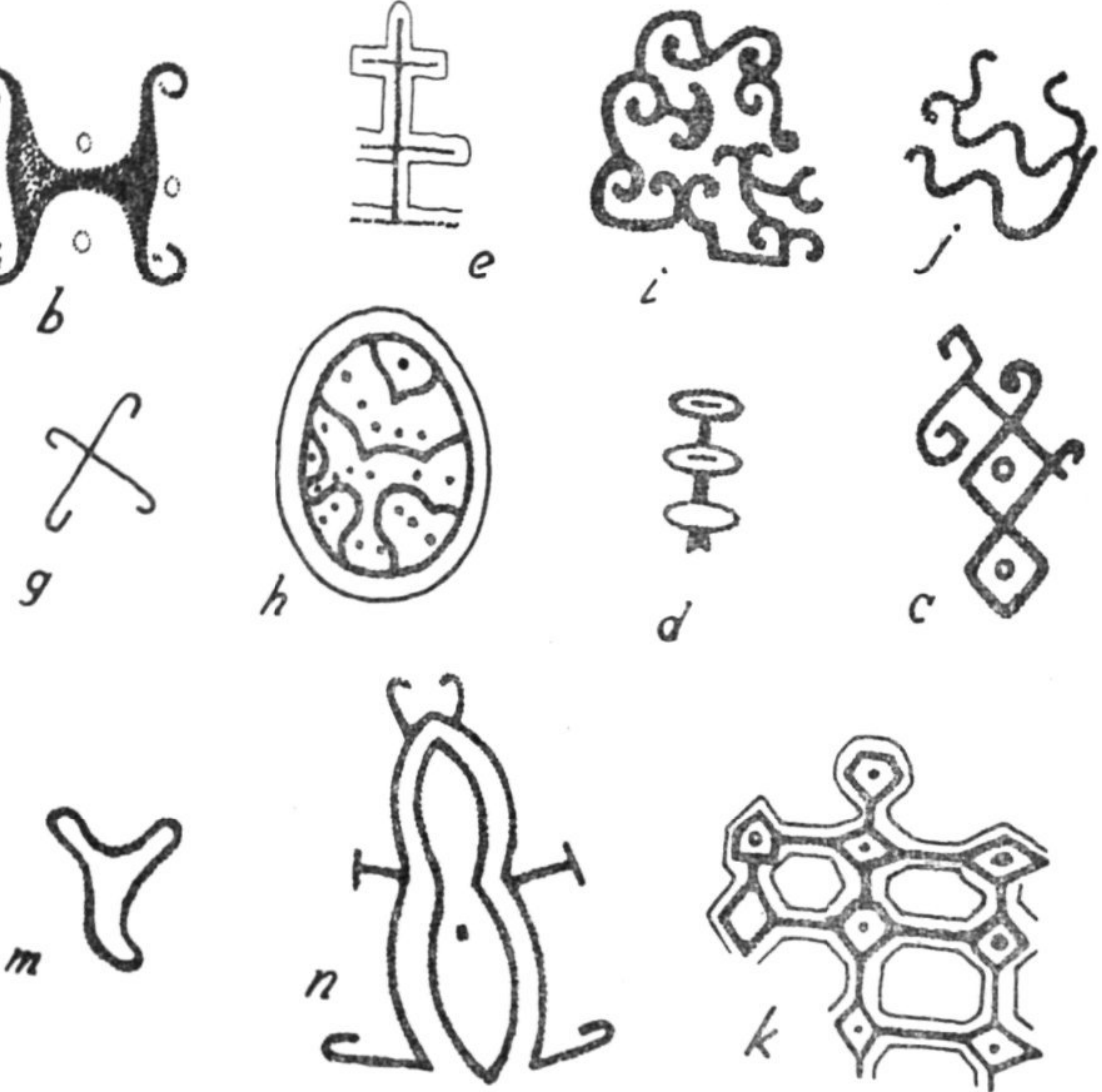

$m$
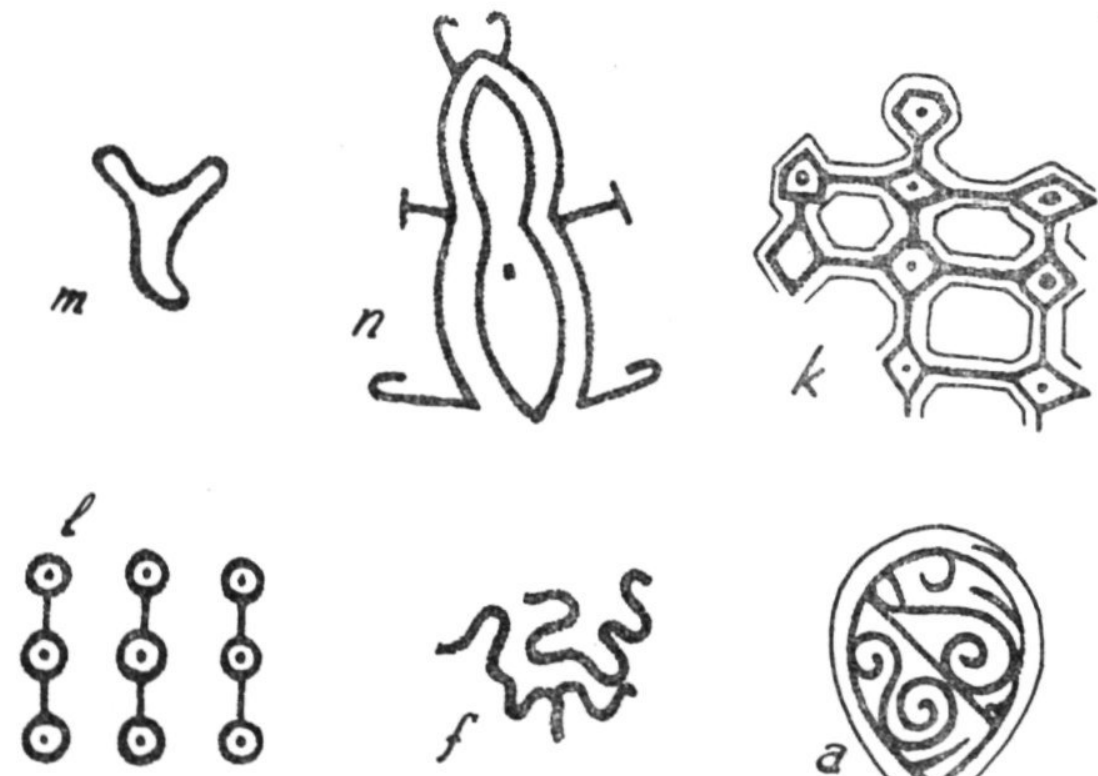

Fig. 3. Enkele rotstekeningen van een bruinachtige rode kleur (met uitzondering van de vier punten in $b$ welke zwart zijn) uit de grot van Fontein op Aruba (A 1), zoals zij door MARTIN, in 1885 en 1888, werden afgebeeld.

Fig. 3. Some figures in red (with exception of the four dots in $b$ which are black) of the cave of Fontein, Aruba (A 1), as copied from Martin, 1885 and 1888 . 
dat bij het vijftig-jarig jubelfeest van dr C. LeEmans, directeur van het Museum van Oudheden te Leiden, werd uitgegeven - heeft men op Aruba ,,reeds op 27 plaatsen indiaansche opschriften ontdekt, terwijl ze tot dusverre op Bonaire slechts op ééne plaats en op Curaçao in het geheel niet gevonden zijn." De meeste Arubaanse ,,inscriptiën zijn met roode, eenige met witte en slechts ééne met zwarte verven aangebracht. Eene enkele figuur is op een granietblok met eenen steen ingegrift.'

Een historische betekenis acht hij in bepaalde gevallen niet onwaarschijnlijk. Een (p. 184) ,,overlevering zegt dat in eene grot van den heuvel Carachito eenige indianen door de franschen (?) (misschien ook wel engelschen?) zijn doodgeschoten. Nu komen op dienzelfden heuvel indiaansche opschriften voor en in een dier opschriften herkent men duidelijk de afbeelding van een schip”. (p. 183) „,De heer Alph. Pinart, die sedert jaren Amerika doorkruist om aanteekeningen over de oude bewoners te maken, getuigt van de opschriften van Aruba dat zij een echt indiaansch (Caraïbisch) karakter dragen en dat ze het meest met die van het naburig Spaansch eiland Puerto Rico overeenkomen."

Toen prof. MARTIN - van 28 Januari tot 10 Februari 1885 - Aruba ten behoeve van zijn geologische studies bezocht, had hij voor de rotstekeningen grote belangstelling. Acht figuren van de Seroe Canashito (fig. 26) en veertien uit de Grot van Fontein (fig. 3) worden er door hem - in dezelfde, aan LeEmans gewijde uitgave (1885, p. 182) - afgebeeld. , Ich habe aus den genannten Höhlen alle charakteriktischer, gut erhaltenen Figuren, welche ich auffinden konnte, abgebildet und hierunter meine ich wohl Thierformen und ziellose Spielereien, nicht aber eine Schrift zu erkennen. So halte ich No. 17 [A $1 n]$ für einen Frosch, No. 12 und $21[$ A 1 $j, f]$ für Schlangen; der Figur 14 [A $1 h$ ) dürfte vielleicht eine Schildkröte, der Figur 18 [A $1 k]$ eine Koralle zu Grunde liegen; unverkennbar ist der in No. 5 [A 5j] dargestellte Stern."

In het reisverhaal, dat MARTIN - iets eerder in hetzefde jaar - publiceerde, zegt hij over hetzelfde onderwerp (p. 356): , Leider sind die mit Eisenocker angefertigten Linien der bis $1 \mathrm{~m}$ grossen Darstellungen durch unberufene Hände vielfach beschmiert worden. Schwarze Figuren, darunter ungeschickte Nachahmungen der älteren, befinden sich daneben und gleich gefärbte Linien und Punkte verderben bisweilen das ursprüngliche Bild, so dass man bei der Wiedergabe des Letzteren vorsichtig zu Werke gehen muss."

,Noch eine Reihe von solchen Höhlen ist .... auf dem Wege von Fontein nach Colorado zu vorhanden; zwei derselben, etwa $\frac{1}{2}$ Wegstunde .... entfernt, besuchten wir .... Die Fontein zunächst gelegene .... Zeichnungen fanden sich hier nicht, wohl aber in einer folgenden, weit minder geräumigen Höhle, in der zwei rohe menschliche Figuren und Nachahmungen vierfüssiger Thiere deutlich erkennbar waren. Ganz ähnliche Bilder, nur weit vollständiger, hatte ich nachher Gelegenheit im Hause des Herrn van Kooleijk, der sie nachgezeichnet, zu sehen; an diesem Orte waren đie Zeichnungen aber zu sehr verwischt, als dass eine getreue Wiedergabe möglich gewesen wäre."

Het eerste deel van het bekende werk over MARTIN's geologische onderzoekingen (1888, p. 133-135, tab. xIv 1-22) vertelt ons - naast een aantal reeds bekende feiten, waarbij de afbeeldingen uit LEEMANs' gedenkboek nog eens worden afgedrukt - dat er op Bonaire indianen- 

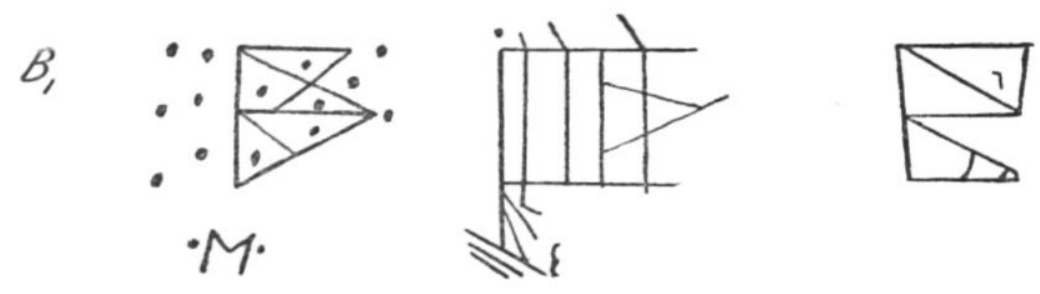

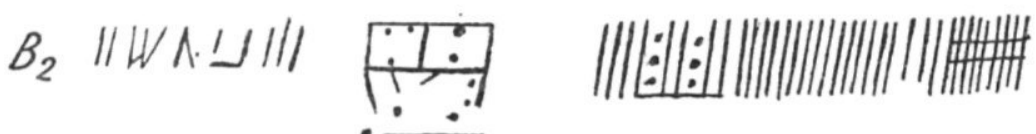
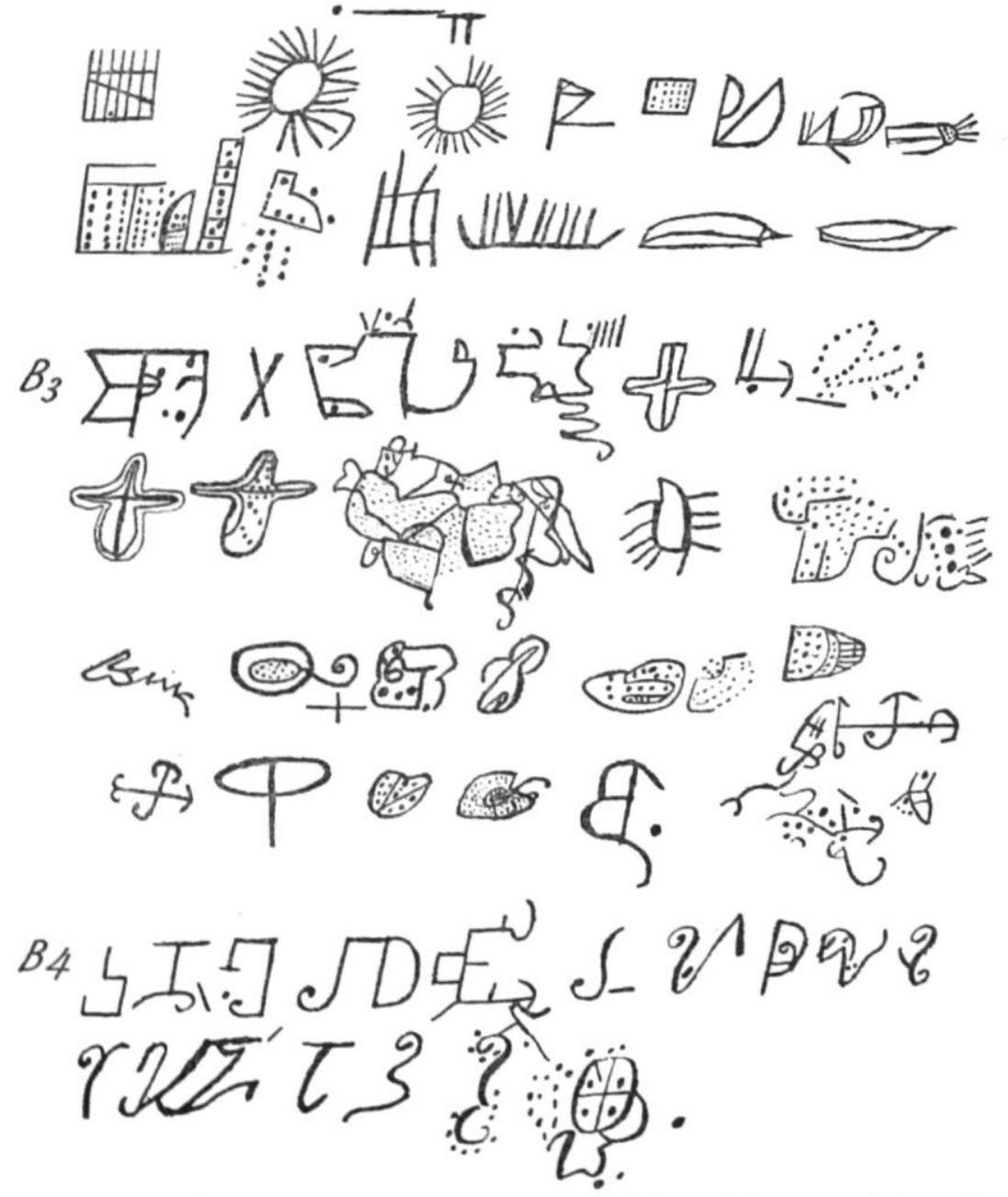

Fig. 4. Enkele rotstekeningen in een roodachtige of (voor wat betreft B 2) ook wel blauwachtige kleur, van de noordkust van Bonaire in de buurt van Onima (B 1-4), zoals zij werden getekend door pastoor vAN KOoLWIJK in 1875 en gepubliceerd door pater EUWENS in 1907. Fig. 4. Some figures in red and (as regards B 2) blue, of the northern coast of Bonaire (B1-4) as drawn by vaN KoolwIJK in 1875, and published by EuwENS, 1907. 
tekeningen (p. 134) , an zwei Punkten gefunden sind und zwar an der Bucht von Onima, am Nordstrande unweit Fontein .... und an der Nordwestküste, südlich von Playa Franz, unmitterbar nördlich vom Waikuru." Voorts wordt de aandacht gevestigd op het feit dat de rotstekeningen op de eilanden een onmiskenbare gelijkenis vertonen met soortgelijke figuren welke SсномвURGк in het verslag van zijn reizen in Guyana en het Orinoco-gebied heeft afgebeeld.

Alphonse Pinart - die door van KoolwiJk als een in oudheden belangstellende bezoeker van Aruba wordt genoemd - was een jong Frans onderzoeker, die - na vele, op wetenschappelijk gebied zeer vruchtbare reizen welke zich van de oevers van de Behring Zee tot aan het Paas Eiland uitstrekten - ook dit eiland bezocht. Tal van beschouwingen over de bevolking, de taal en de oudheden van de streken welke hij bereisde legde hij vast in geschreven verhandelingen, welke hij, met schetstekeningen voorzien, als fac-simile vermenigvuldigde en op beperkte schaal verspreidde. Volgens zijn mededeling over de Grote Antillen (1890a, p.6, plaat 4 fig. 2) vond hij op Puerto Rico figuren welke hem aan oude schrifttekens herinnerden; ,,dans les pétroglyphes copiés par nous à Aruba .... aussi bien que dans la Chiriqui, dans le département de Panama, nous avons rencontrés des caractères similaires. Nous signalons ce fait mais, nous n' osons pour le moment en tirer de conclusions." Hetzelfde wordt opgemerkt in aantekeningen over de Centraal-Amerikaanse landlengte (1890c, art. 2, p. 2)

Over Aruba schreef hij in hetzelfde jaar een verhandeling (1890b) welke de schrijver van dit overzicht tot zijn grote spijt niet in handen heeft kunnen krijgen. In het grote werk van MALLERY (1893, p. 139-140) wordt (letterlijk) het volgende, als samenvatting van hetgeen PINART over de Arubaanse rotstekeningen mededeelde, gezegd: ,These petroglyphs are quite different in character from those which I have recently described in a brief study of the Greater and Lesser Antilles, and their appearance brings to mind those found in Orinoco, in Venezuela, in the peninsula of Paraguana, on the border of the Magdalena river, and as far as Chiriqui. They differ from these, however, in several respects, and especially in that they are almost always multi-colored. The colors usually employed are red, / blue, a yellowish white, and black. They are, moreover, painted and not cut in the rock. .... The petroglyphs are .... very numerous on the island of Aruba. I have personal knowledge of thirty, but according to my friend Père van Kolwsjk, there must be more than fifty. The most important groups are as follows:

(1) Avikok. An enormous dark rock forms the summit of a wooded knob, and in this rock are two large cavities, one above the other, on the walls of which are the petroglyphs represented.

(2) Fontein. On the border of a fresh-water lagoon, a short distance from the northeast part of the island, near the sea, is a grotto of coralline origin, whose walls are of a remarkable whiteness. This grotto is composed of a principal passage, quite wide, cut off toward the lower end by a row of stalactites and stalagmites, which, joining together, form a curious grimacing figure. On the wall to the left, as we look toward the bottom of the grotto, are found some petroglyphs. They are well preserved, thanks to their situation and the shelter from inclement weather, and they show no indication of painting, being distinctly traced on the walls. 


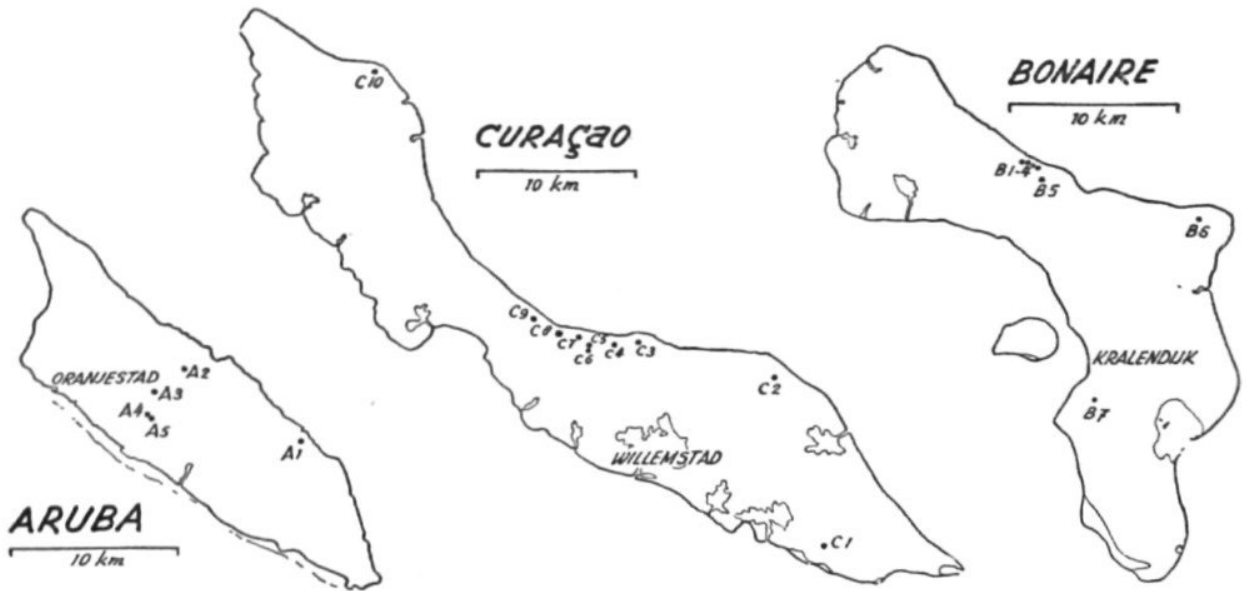

Fig. 5. De ligging van 22 vindplaatsen van rotstekeningen (petrographiën) op Aruba, Curaçao en Bonaire; A 2-3 op dioriet, de andere op kalksteen. Slechts 16 hiervan (A 2-5, C 1-10, B 5 en 7) worden in deze publicatie behandeld. Inscripties (petroglyphen) vindt men alleen bij C 4 . Fig. 5. Index maps of the islands of Aruba, Curaçao and Bonaire with localities in which rude linear designs painted (petrographs) on limestone rock or diorite (A 2-3) are to be found. This publication deals only with A $2-5, C 1-10$, and B 5 and 7 . Linear designs engraved (petroglyphs) in coral rock occur in C 4 only.

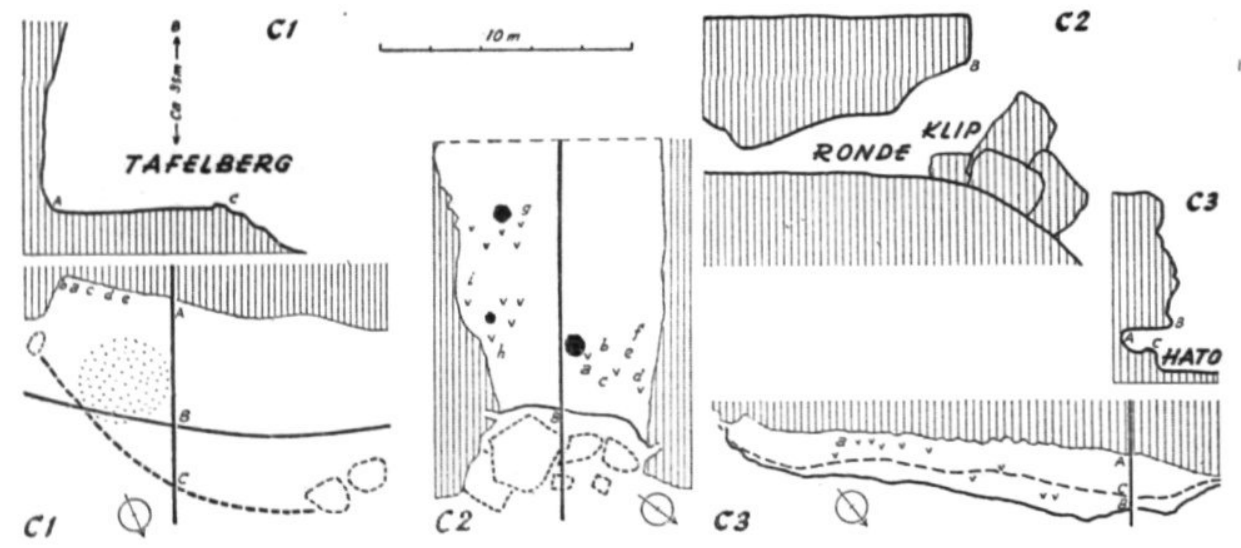

Fig. 6. Platte grond en doorsnede van de vindplaatsen bij de Tafelberg van Santa Barbara (C 1), op Ronde Klip (C 2) en bij Hato (C 3), Curaçao. - De kalksteenrots is gearceerd; de verweerde druipsteenzuilen zijn massief zwart. De rand van het overhangende deel is met een gesloten lijn aangeduid; belangrijke reliëfverschillen van de bodem met een gebroken lijn. De hoofdletters hebben betrekking op de plaats waar de doorsnede is gemaakt; de kleine cursieve letters op de ligging van de afgebeelde tekeningen; de $\mathrm{v}$-tekentjes op die van onduidelijke resten. Fig. 6. Ground plan and cross section of the Tafelberg (C 1), Ronde Klip (C 2) and Hato (C 3) localilities, Curaçao. - Coral rock striped; pillars of weathered dripstone indicated by black dots; figures by $a, b, c$, etc.; vague remnants of red figures by $v-v$. 

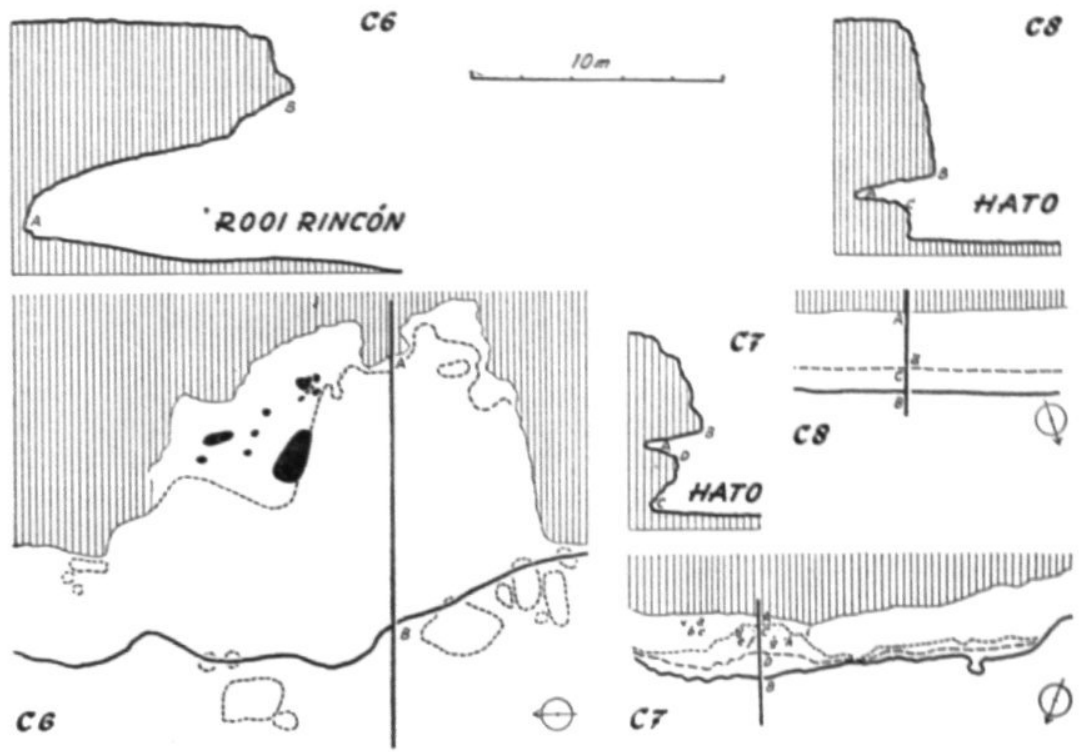

Fig. 7. Platte grond en doorsnede van de vindplaatsen van Rooi Rincón (C 6) en Hato (C 7-8), Curaçao, - Voor de verklaring zie fig. 6.

Fig. 7. Ground plan and cross section of the localities at Rooi Rincón (C 6) and Hato (C 7-8), Curaçao.
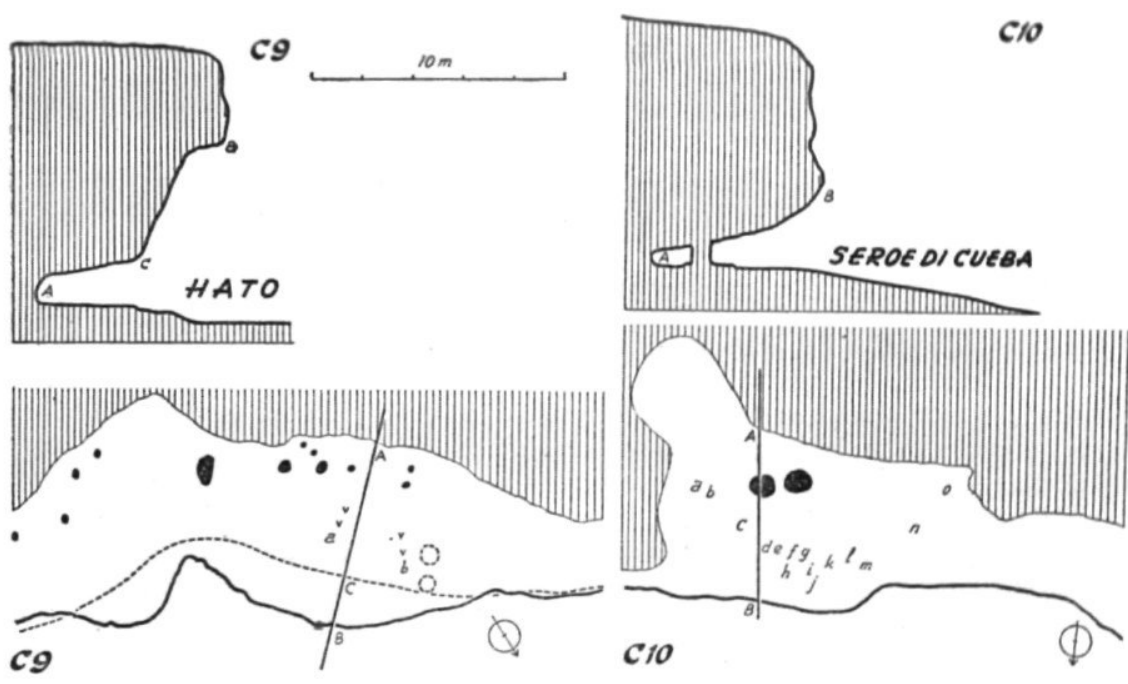

Fig. 8. Platte grond en doorsnede van de vindplaatsen van Hato (C 9) en de Seroe di Cueba, Curaçao (C 10). - Voor de verklaring zie fig. 6 (Fig. 6-8 en 25 naar tekeningen van A. D. Ringma).

Fig. 8. Ground plan and cross section of the localities of Hato (C 9) and Seroe di Cueba (C 10), Curaçao. 
(3) Chiribana. On some granitic spurs of a hill of the same name are found curious petroglyphs.

(4) At Lero de Wajukan, near Avikok, and at the foot of a hill, petroglyphs are found on some blocks of granite. I notice specially the human figure which in the original is outlined in red and bears on the shoulder a hatchet of the Carib type with a haft.

(5) At Ayo I discovered petroglyphs with figures in blue and red.

(6) At Woeboeri inscriptions are found on the wall of an immense mass of granite.

(7) Some petroglyphs on the walls of a grotto at Karasito."

De geschiedvorser pater Euwens (1907, p. 194) is de eerste die ons in een kort historisch overzicht van het eiland Bonaire - bijzonderheden mededeelt over ,,eenige hieroglyphische opschriften en teekeningen" welke ,,men nog op het Noord-Westelijk deel van Bonaire in een grot op de plantage $\mathrm{F}$ o $\mathrm{nte}$ i $\mathrm{n}$, verder in de zoogenaamde $\mathrm{Spel}$ o $\mathrm{nk}$ op de plantage Bolivia, en op een rotsblok bij Onima" vindt. In dit artikel geeft hij een afbeelding van ,,Oud-Indiaansche opschriften op Bonaire bij Onima, door den Z.E.H. A. J. van Koolwijk, destijds pastoor van Rincón, in 1875 nageteekend"' (fig. 4).

Vier jaar later vermeldt pastoor EUwENS - in een soortgelijk overzicht van het eiland Aruba - nog de aanwezigheid op dit eiland ,op ongeveer 30 verschillende, vèr uit elkander liggende plaatsen" van ,,een overgroote menigte opschriften en teekeningen langs de wanden en tegen de gewelven van grotten, onder uitgeholde, ontzaggelijke graniet.... blokken en rotswanden, ongeveer van denzelfden raadselachtigen vorm, doch in grooter verscheidenheid dan de hieroglyphen van Bonaire", zonder er nieuwe bijzonderheden aan toe te voegen.

Een korte samenvatting van onze kennis van de rotstekeningen van Aruba en Bonaire geeft, in 1916, de volkenkundige TEN KATE. Hij acht, op Bonaire (p. 544) ,,Vooral die teekeningen, welke aan de O-zijde van de rots van Ceroeplat voorkomen ..... zeker onder Europeeschen invloed ontstaan, daar men er gebrekkig uitgevoerde Latynsche hoofdletters onder vindt. Ook komt een ,,M” aan de N.-zijde van Ceroeplat op de rots voor." Wat de figuren van Fontein en de Canashito op Aruba betreft: „Behalve een aantal nondescript figuren, zijn er andere die vermoedelijk dieren voorstellen; verder een duidelijke ster. Naar analogieën besluitend, is het waarschijnlijk, dat er ook hier geen sprake is van ,,ziellose Spielereien", natuurlijk met uitzondering der Latijnsche letters van Ceroeplat. Veeleer heeft men hier te doen met gebedsritueelen, in verband met de offergaven, die in de rotsholen werden gebracht. Het is niet onmogelijk, dat de menschenbeenderen en fragmenten van aardewerk, die men in enkele grotten heeft gevonden, met de pictographieën in verband staan.'

Dit opstel over de „,Oudheden” van „,De W.I. Eilanden” geeft TEN KATE aanleiding tot het maken van de veronderstelling, dat op de Benedenwindse Eilanden, behalve een Caraïbisch, nog (p. 545),,een ander ethnisch element onder de inlandsche bevolking voorkwam en dat dit element behoorde tot de groote familie der Arawakken of Arowakken." Als één van de gronden voor zijn werkhypothese noemt hij ,,De artifacten en pictographieën, vooral van Aruba”, die kenmerken vertonen , die niet uitsluitend Karaïbisch zijn." 


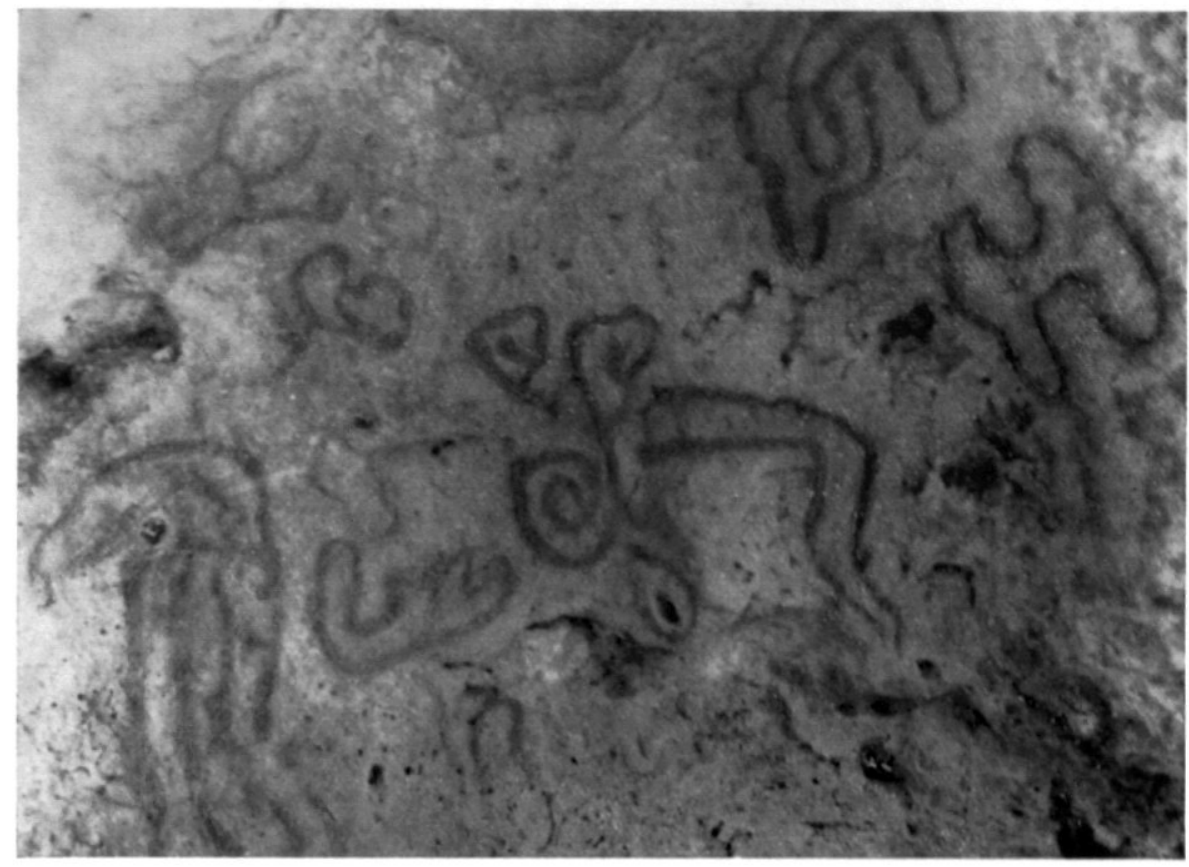

Fig. 11. Vage tekeningen op kalksteen aan de noordrand van de Seroe Canashito, Aruba (A $4 c, d$; vgl. fig. 27-28; de figuren zijn op de foto iets verduidelijkt). Fig. 11. Vague designs in red of the Seroe Canashito, Aruba (A $4 c$, d; cf. fig. 27-28).

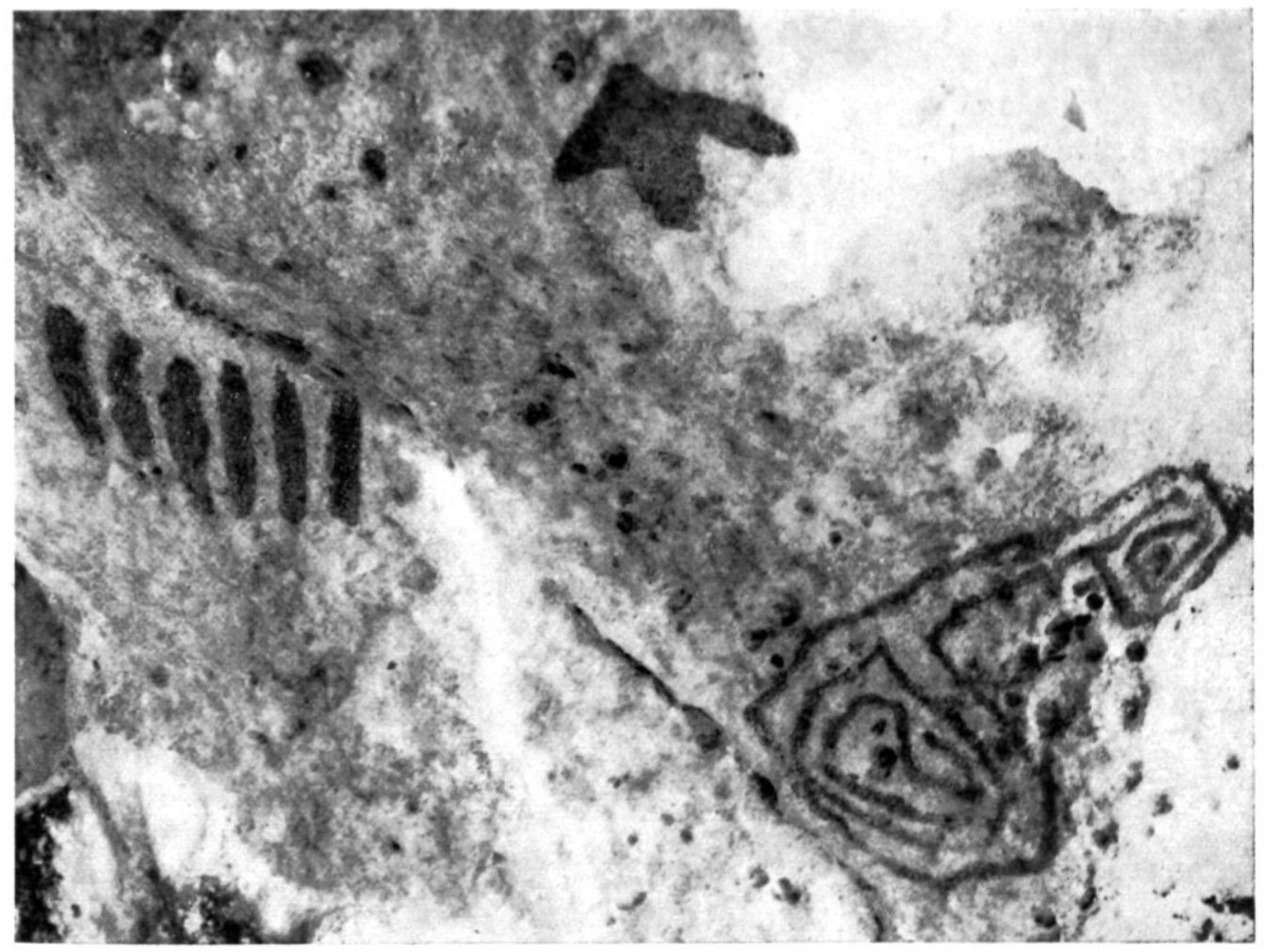

Fig. 12. Enkele rotstekeningen uit een kleine grot in de Seroe Canashito, Aruba (A $5 e, g-h$; vgl. fig. 26-27, 29).

Fig. 12. Petrographs in red of the Seroe Canashito, Aruba (A 5e, g- h; cf. fig. 26-27, 29). 


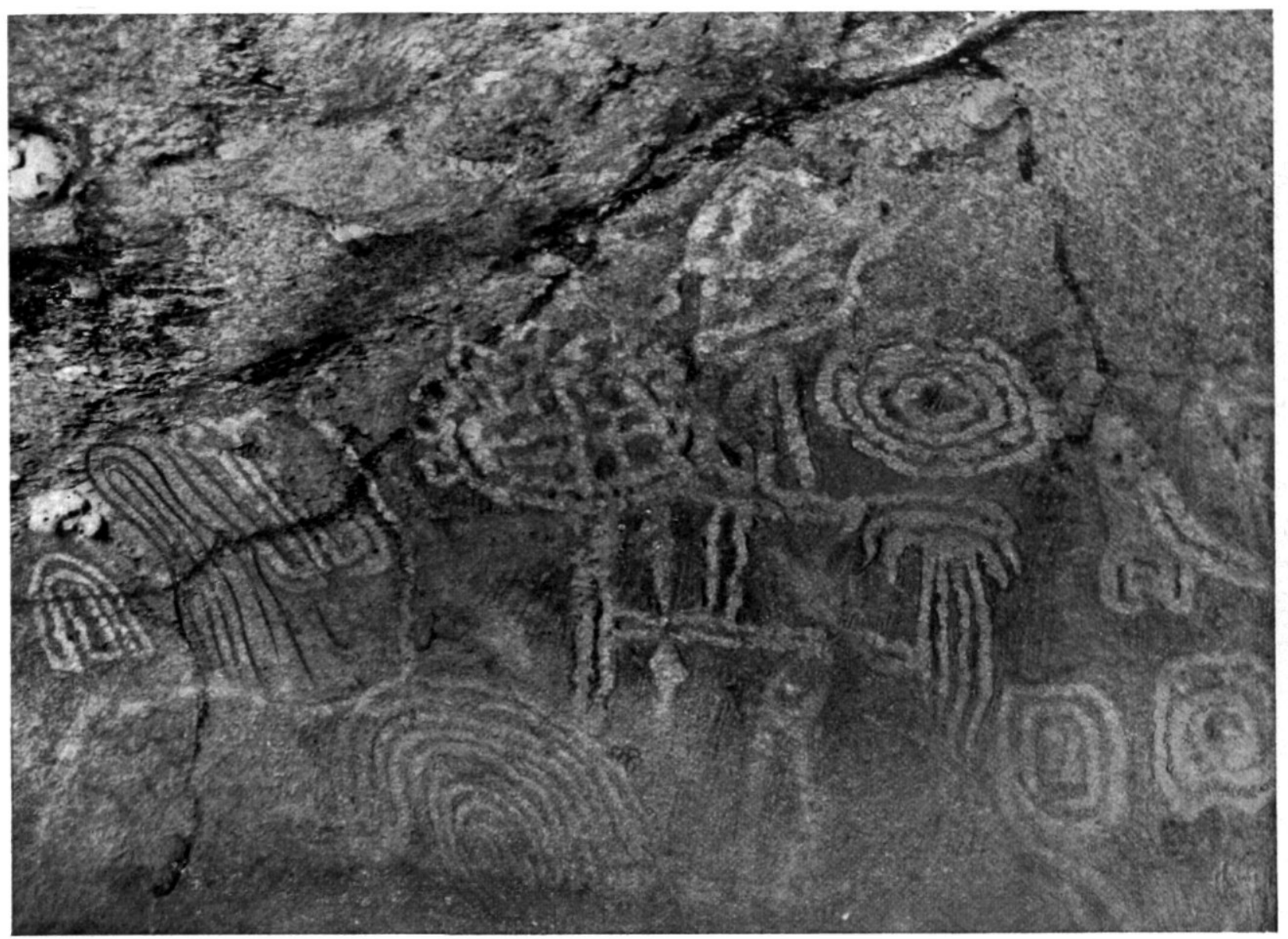

Fig. 13. Tekeningen in wit en rood in een verweringsholte van een groot diorietblok bij Ajó, Aruba (A $2 b-l$; vgl fig. 14, 32; de donkere streep welke van links-onder naar rechts-boven loopt, met zijn vertakkingen, is een oude insectengang).

Fig. 13. Petrographs in white and red on quarz-diorite, in a small cave at Ajó, Aruba (A 2b-l; cf. fig. 14, 32; the curved, bifurcated line, running from bottom-left to top-right is made by insects). 


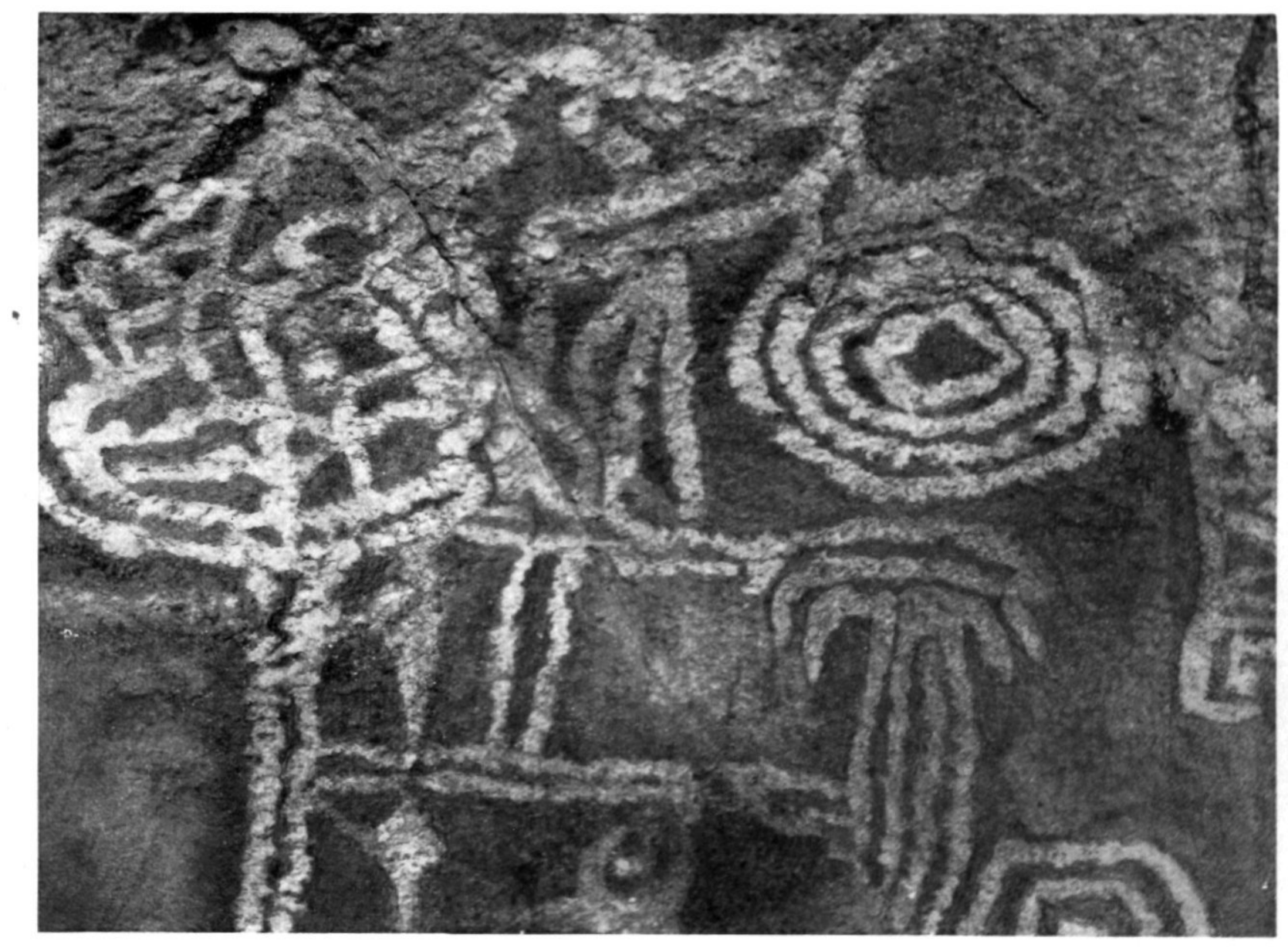

Fig. 14. Een deel van de witte rotstekeningen van Ajó, A ruba (A 2e-l; vgl. 13, 32; de witte tekening op fig 14 en 15 is iets verduidelijkt door op de foto's bepaalde lichtere partijen van de donkere ondergrond weg te werken). Fig. 14. A part of a rock drawing in white, to be found at Ajó, Aruba (A 2e-l; cf. fig. 13, 32). 


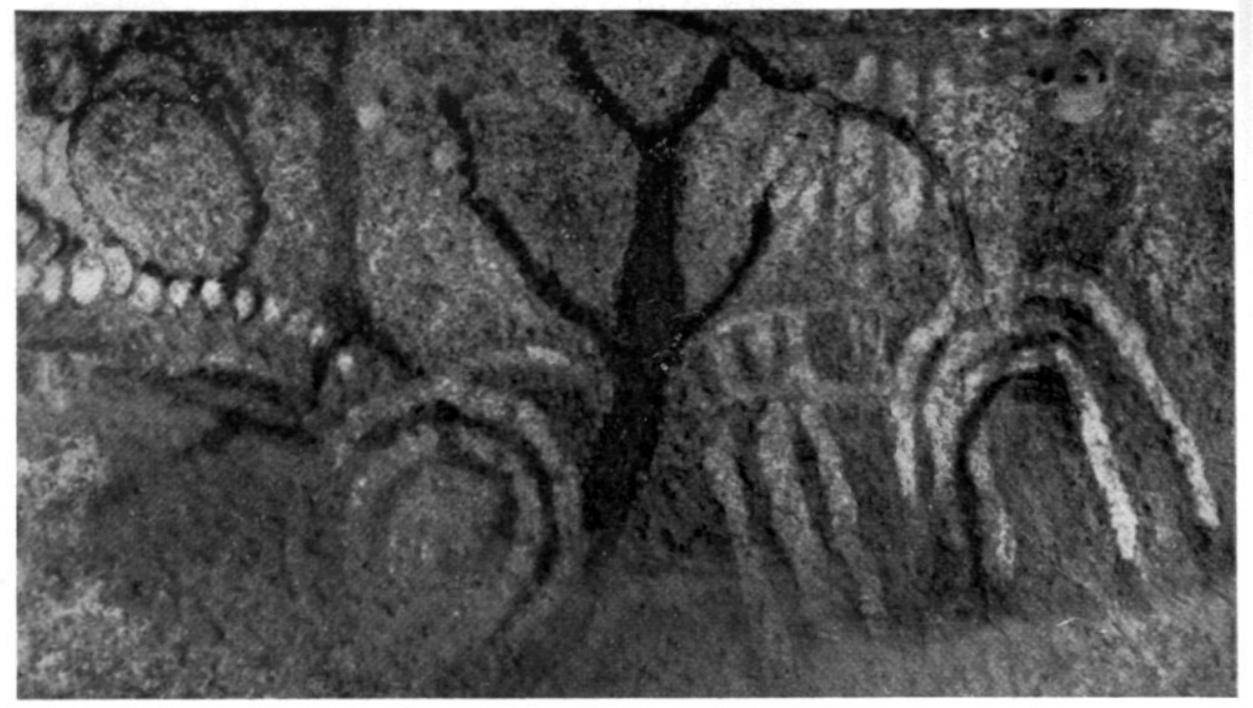

Fig. 15. Tekeningen in wit en rood in een verweringsholte van een groot diorietblok bij Ajó, Aruba (A 2a; vgl. fig. 32; de onregelmatig gebogen streep welke van het midden-rechts naar het midden-boven loopt is de rest van een insectengang).

Fig. 15. Linear designs in white and red on quarz-diorite in a small cave at Ajò, Aruba (A 2a; cf. fig. 32; the curved line running from right-center to the top is made by insects).

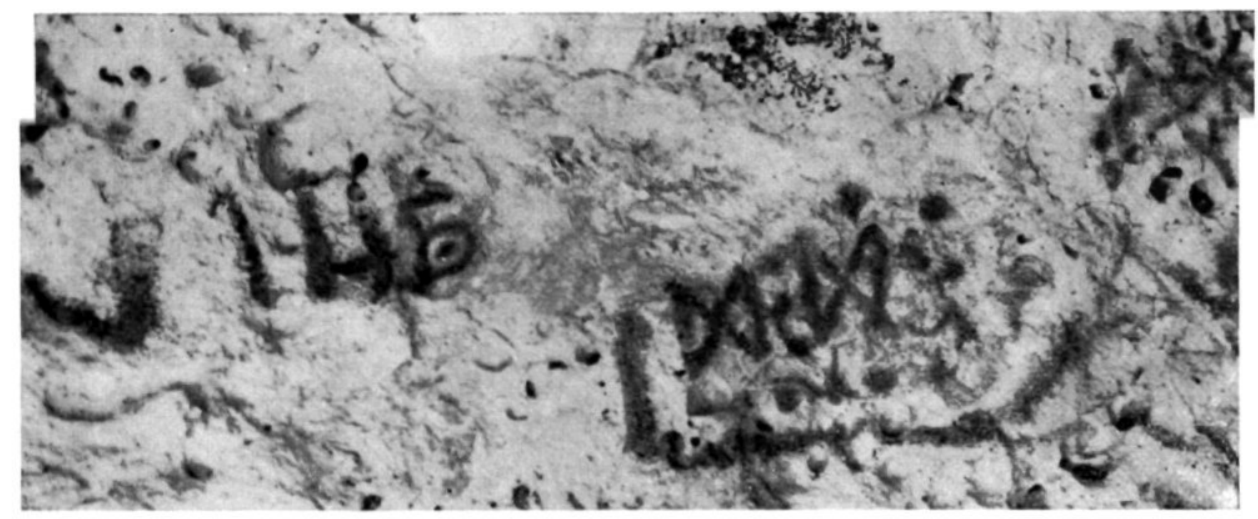

Fig. 36. Rode tekens op ruwe kalksteen bij Pos Calbas, op Lima, Bonaire (B $7 d, m$; vgl. fig. 34-35).

Fig. 36. Marks in red on coral rock of Pos Calbas, Bonaire (B 7d, $m$ cf. fig. 34-35). 
In later jaren is er niet veel meer aan onze kennis van de rotstekeningen toegevoegd. AMELUNXEN (1929, p. 10) geeft een afbeelding van een deel van de door EUWENS gereproduceerde tekeningen van VAN KooLwIJK (fig. $4 \mathrm{~B} 1-2$ ), in iets gewijzigde vorm. In een artikel van WoLlEBAEK (1934, fig. 7) vinden wij nog eens het ,,kikkermotief" (A1 $n$ ) zoals dit door MARTIN werd afgebeeld. Rings geeft in 1943 (p. 6) enkele krabbels van tekeningen uit de grot van de Seroe Canashito - welke hij in hetzelfde jaar had bezocht - waarin wij enkele bekende, reeds door MARTIN gegeven beelden herkennen (A5 $e, g, i, j, l, x)$

Foto's van enkele ornamenten uit de Grot van Fontein (A1 $b, c, d, n)$ - gemaakt door WAgenaAR HUMMELINCK in 1930 en 1936 - komen voor in het aardrijkskundeboekje van frater REALiNo (1938, p. 129), in een artikel van WEStermanN (1947, fig. 2-3) en in het Gedenkboek (1948, fig. 6 (d) en (e)).

In een kort stukje van Hartog $(1951$, p. 5) vinden wij - naast een reproductie van de afbeelding van MARTIN - een foto met tekeningen van de ,,grotto near Piedra Plat. Recognizable are a scorpion-like design $\ldots .$. and a branch, or possibly a hand...." (A $3 d, e, f)$.

De tekens van Pos Calbas op Bonaire (fig. 34) werden in 1944 ontdekt en afgebeeld door pater BRENNEKER, terwijl wij in de fotoreportage over de Nederlandse Antillen van van DE Poll (1950, p. (169)) de reproductie van een foto van vier ,,Bruin-rode Indiaanse tekens op de wand" van de grot van Spelonk aantreffen. De tekeningen van Spelonk ziet men ook op een foto in Nos Tera (1952, p. 93).

\section{BESCHRIJVING VAN DE VINDPLAATSEN OP CURAÇAO}

Een zeer indrukwekkend landschap vindt men op Curaçao aan de Noordzijde van de $\mathrm{T}$ a f e l b e r g van Santa Barbara, daar waar de dikke kalksteenkap - door de snellere verwering van het onderliggende diabaasgesteente ondermijnd - aan de landzijde afbrokkelt, en enorme rotsblokken op een grillige wijze beneden aan de puinhelling verspreid liggen.

\section{(C 1) Tafelberg (fig. 6, 9, 16,17)}

Een plaats aan de voet van een tientallen meters hoge, iets vooroverhellende rotswand is ons doel; een plek, volkomen open naar het Noorden en Noordoosten, met een prachtig uitzicht over het eiland, tot aan de blinkende zee aan gene zijde. Het is er heerlijk fris, en gedurende de meeste van het jaar is men er beschut tegen de felle stralen van de middagzon.

Op een effen gedeelte van deze rotswand - het duidelijkste op een plaats welke nog enigszins tegen regen en wind is beschut, vinden wij hier verbleekte, met een bruinrode kleurstof aangebrachte tekeningen (fig. 9, 16-17), welke waarschijnlijk deel hebben uitgemaakt van een beschildering welke een groot deel van deze wand bedekte.

Opvallend zijn de grote massa's schelpen van eetbare weekdieren uit de ondiepe kustwateren die hier - op ongeveer 150 meter hoogte - en ook verder op, in de nabijheid van de rotsmuur liggen opgehoopt. Het vermoeden ligt voor de hand, dat deze plek vele jaren lang een belangrijke functie heeft gehad als plaats van samenkomst van het volk, waartoe de makers van de tekeningen behoorden. 

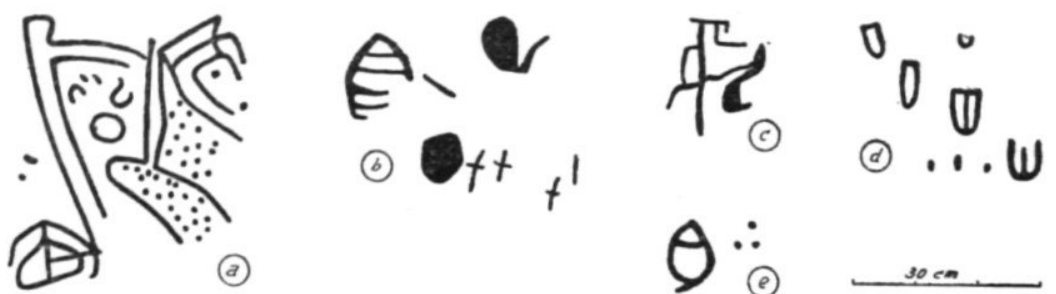

TAFELBERG

$\theta \therefore$

(e)

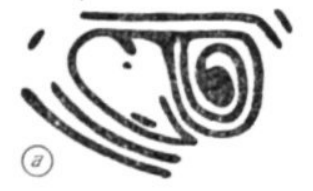

$\vdots \vdots$

()

$(1,1)$
$1, \cdot 0$
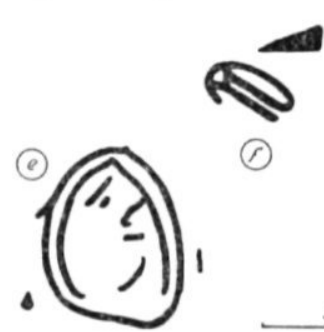

(C)
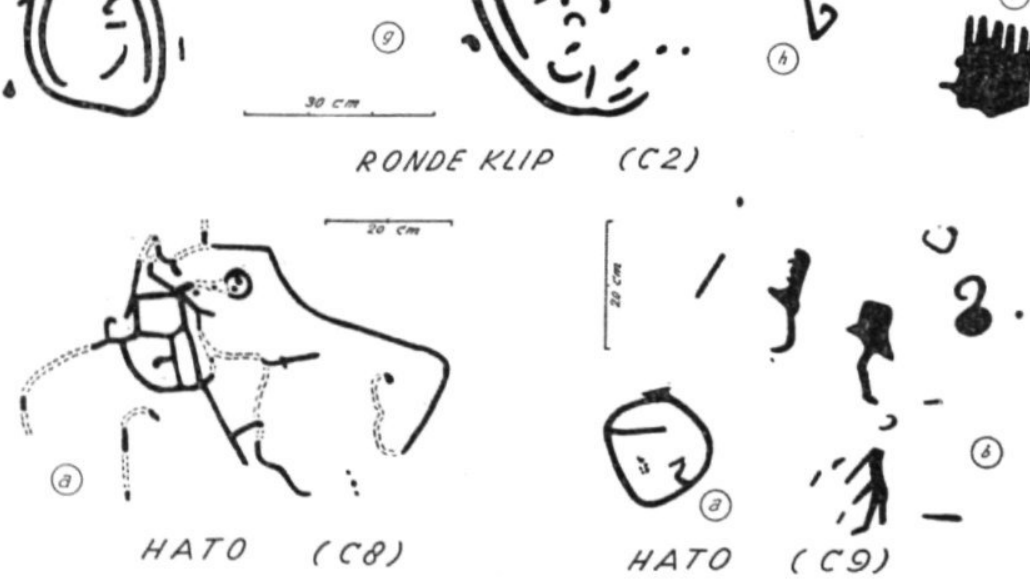

Fig. 16. Resten van rotstekeningen zoals zij nog op de Tafelberg van Santa Barbara (C 1), op Ronde Klip (C 2) en langs de kust van Hato (C 8-9), Curaçao, voorkomen, en door A. D. Ringma in het veld werden geschetst.

Fig. 16. Remnants of linear designs in red of the Tafelberg (C 1), Ronde Klip (C 2) and Hato (C 8-9), Curaçao, as sketched in the field by Ringma. 


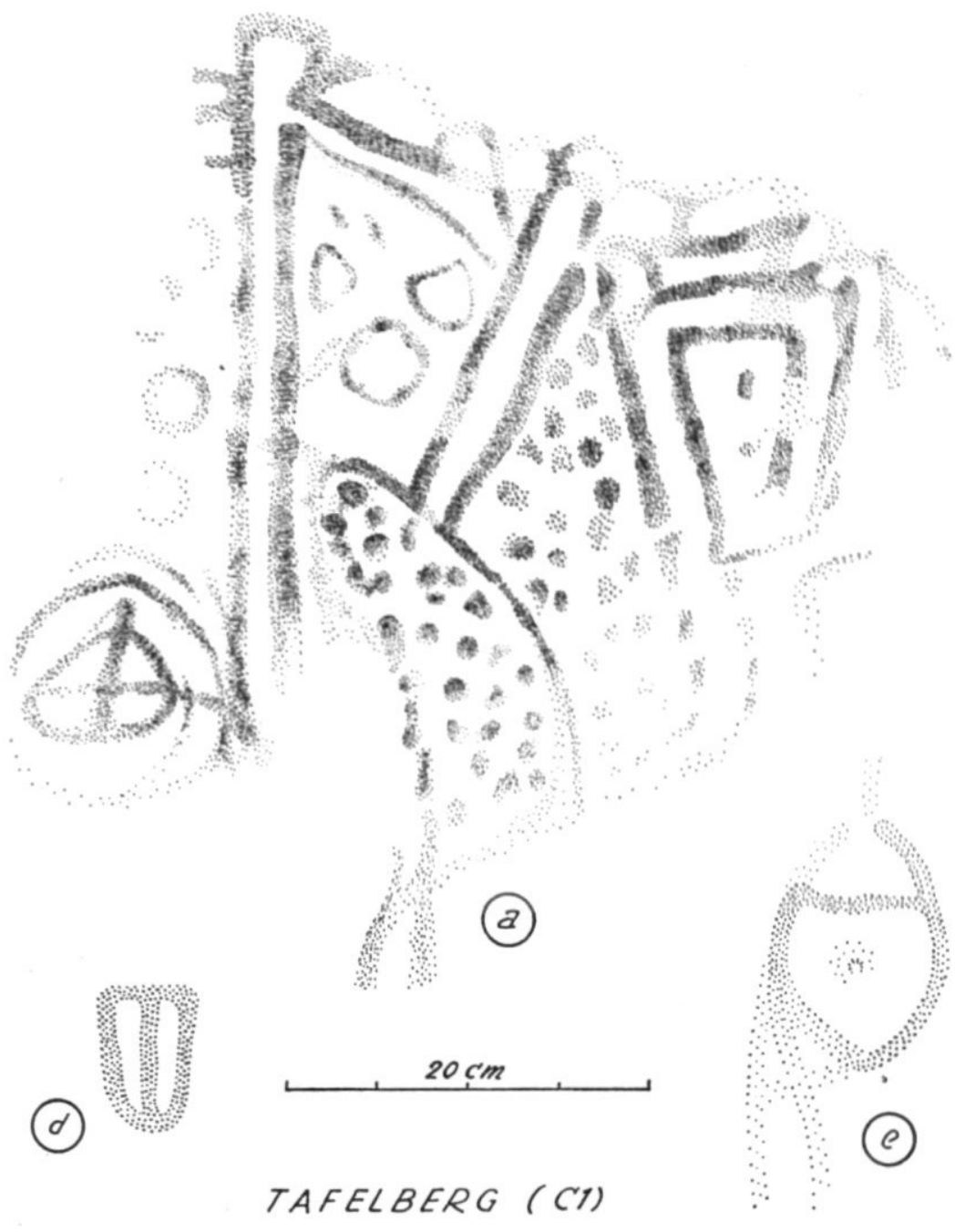

Fig. 17. Enkele tekeningen van de Tafelberg van Santa Barbara (C 1), Curaçao, zoals zij door de schrijver werden gezien.

Fig. 17. Some of the figures from the Tafelberg, Curaçao (C 1), as seen by the author. 


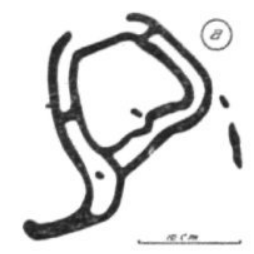

HATO (C3)

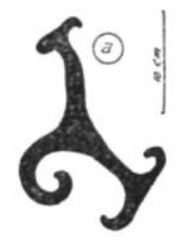

HATO (C4)

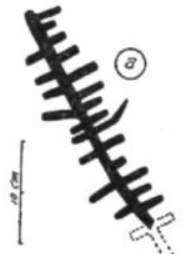

ROOI RINCON (CO)

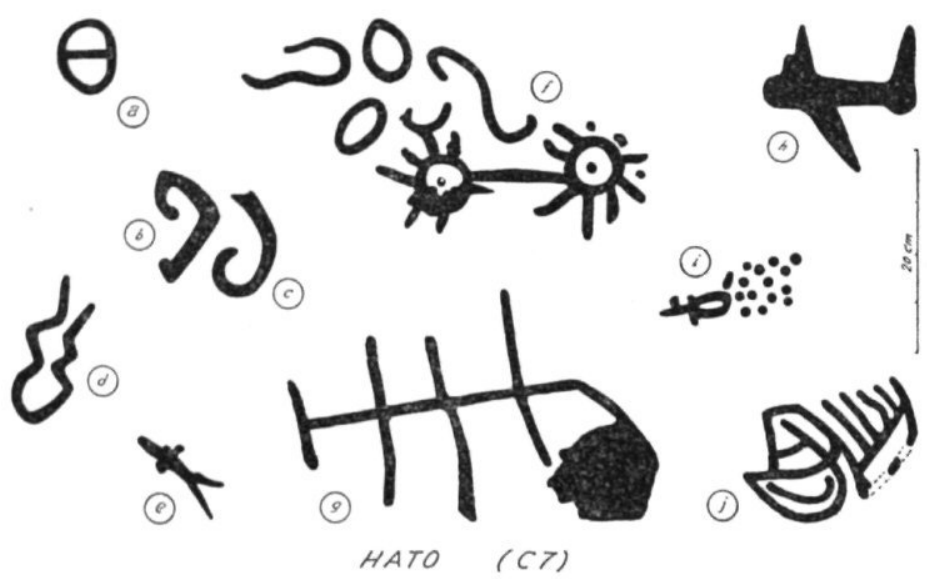

Fig. 18. Rotstekeningen zoals zij worden gevonden langs de kust van Hato (C 3-4, 7) en in Rooi Rincón (C 6), Curaçao, in het veld geschetst door A. D. Ringma.

Fig. 18. Rock drawings in red of Hato $(\mathrm{C} 3-4,7)$ and Rooi Rincón (C 6), Curaģao, as sketched by RINGMA.

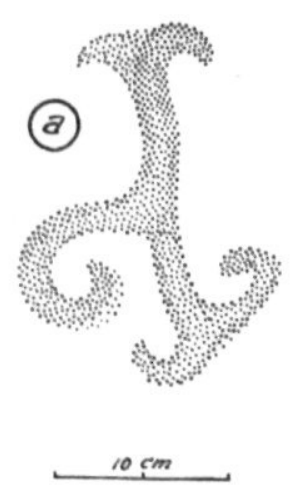

HATO $(C 4)$

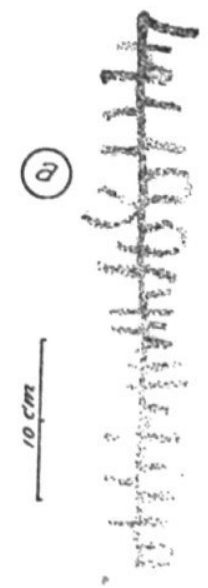

ROOI RINCÓN C6

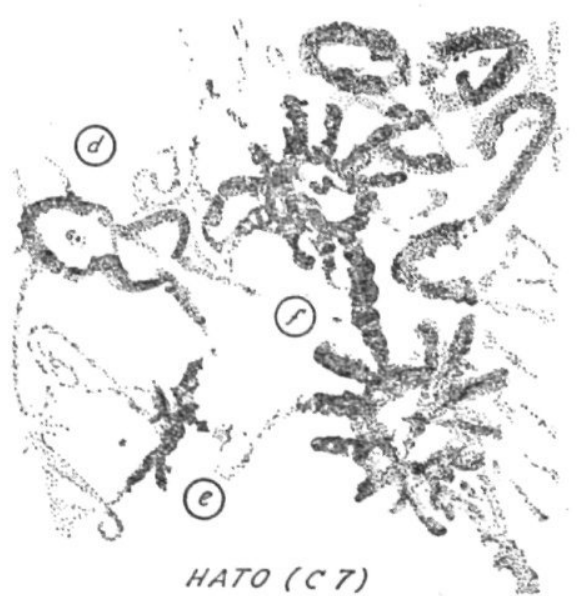

HATO ( C T)

Fig. 19. Enkele figuren van Hato (C 4, 7) en Rooi Rincón (C 6), Curą̧ao, zoals zij in het veld werden geschetst door de schrijver (C 4,6$)$, en van een foto van P. VAN DER WERF nagetekend (C 7).

Fig. 19. Some of the figures of Hato $(\mathrm{C} 4,7)$ and Rooi Rincón (C 6), Curafao, as seen by the author, the first from field notes, the latter from a photograph. 


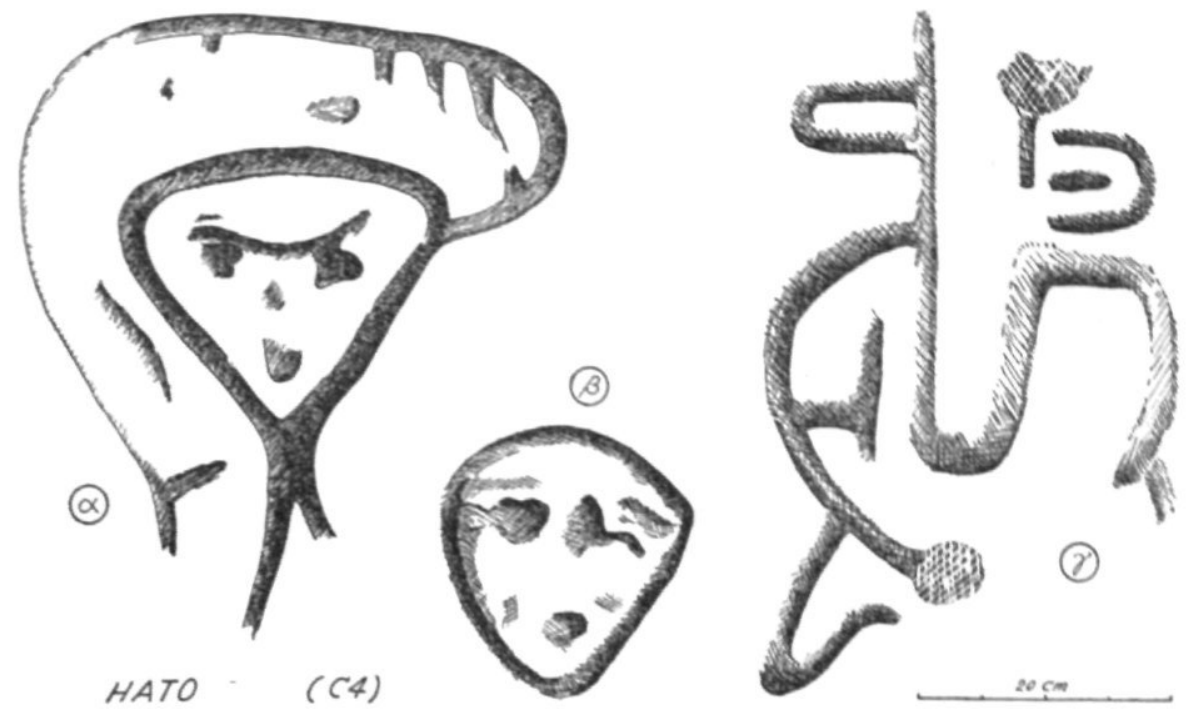

Fig. 20. Enkele verweerde, in ruwe koraalrots gehouwen tekeningen, door A. D. Ringma bij Hato (C 4), Curaf̧ao, gevonden en geschetst. Fig. 20. Some remnants of designs engraved in rough coral limestone near Hato (C 4), Curafao, as sketched in the field by Ringma.

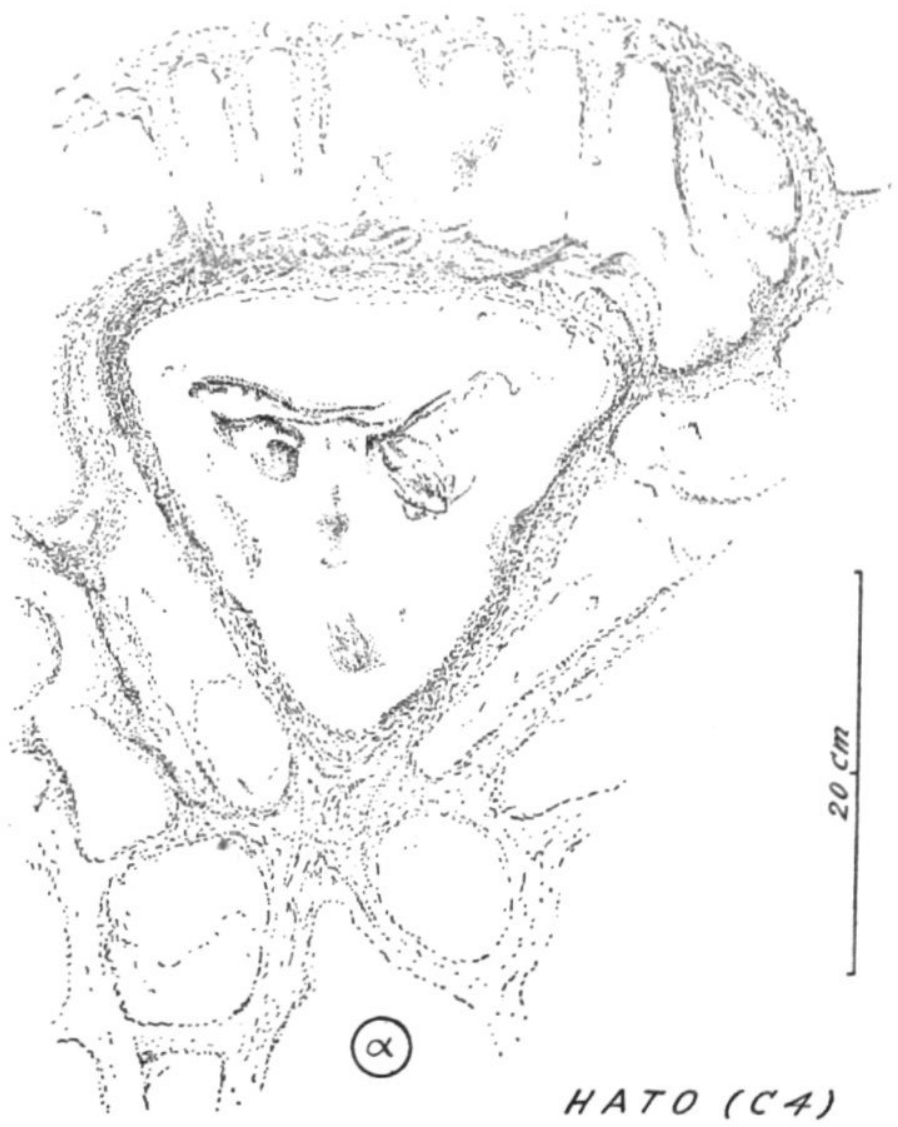

Fig. 21. Een van de reliefs van Hato (C 4), Curaçao, waarschijnlijk een menselijk gezicht met hoofdtooi voorstellende, door de schrijver getekend. Fig. 21. One of the petroglyphs of Hato (C 4), Curaçao, from a drawing by the author, probably representing a human face with head dress. 

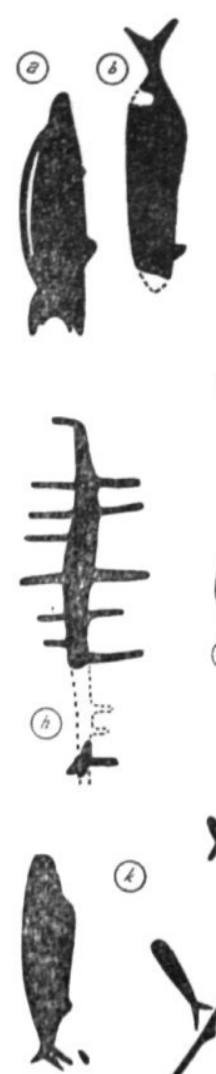

(4)

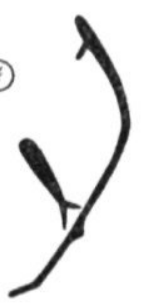

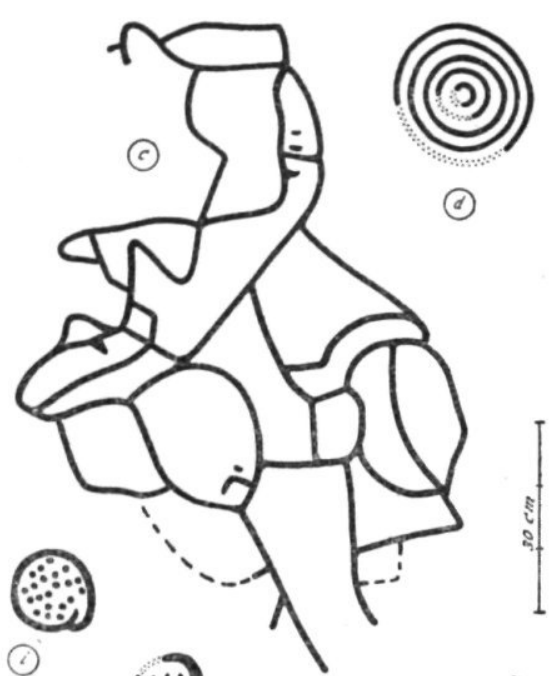

(๑)

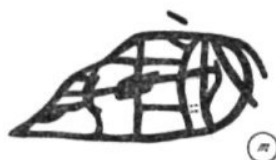

(-)

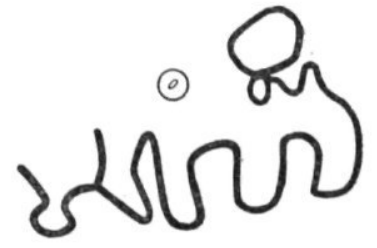

( $(10)$

Fig. 22. Rotstekeningen uit het abri van de Seroe di Cueba (C 10), Curaf̧ao, uitgevoerd in een bruinachtig rode kleur, zoals zij door A. D. RiNGMA werden nagetekend. - De figuren $a, b$, en $k$ lijken op vissen; $m$ heeft iets van een varken en $n$ doet denken aan een vogel.

Fig. 22. Figures of the rock shelter of the Seroe di Cueba (C 10), Curaçao, made in a reddish colour, as copied by Ringma. - The designs $a, b$ and $k$ are called ,, the fishes"; $m$ named ,,the swine"; $n$,,the bird".
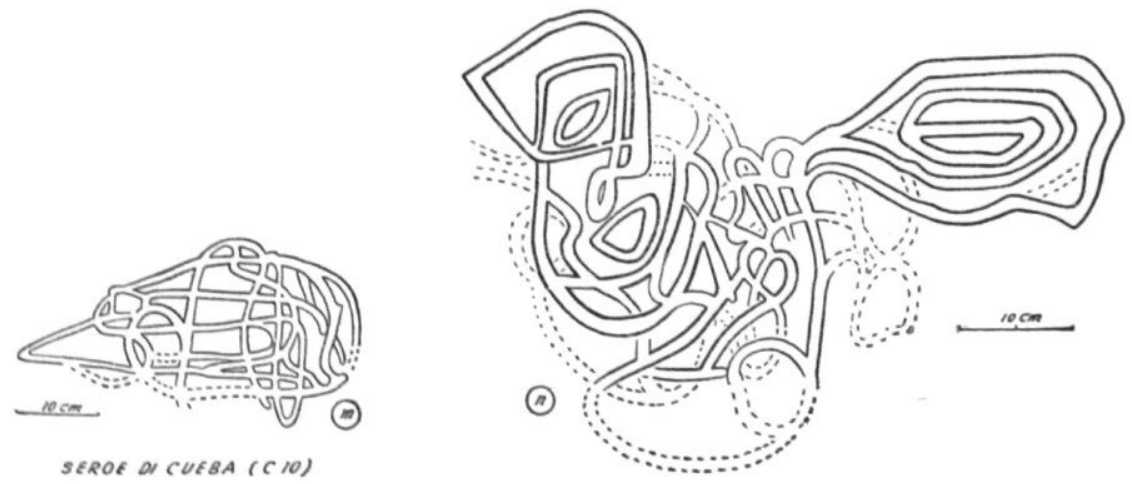

Fig. 23. Een poging tot reconstructie van de figuren van de Seroe di Cueba (C 10), Curaçao, welke ,,het varken” $(m)$ en ,,de vogel” $(n)$ worden genoemd.

Fig. 23. Tentative reconstruction of the figures of the Seroe di Cueba (C 10), Curaçao, called ,the swine" $(m)$ and ,,the bird" $(n)$. 

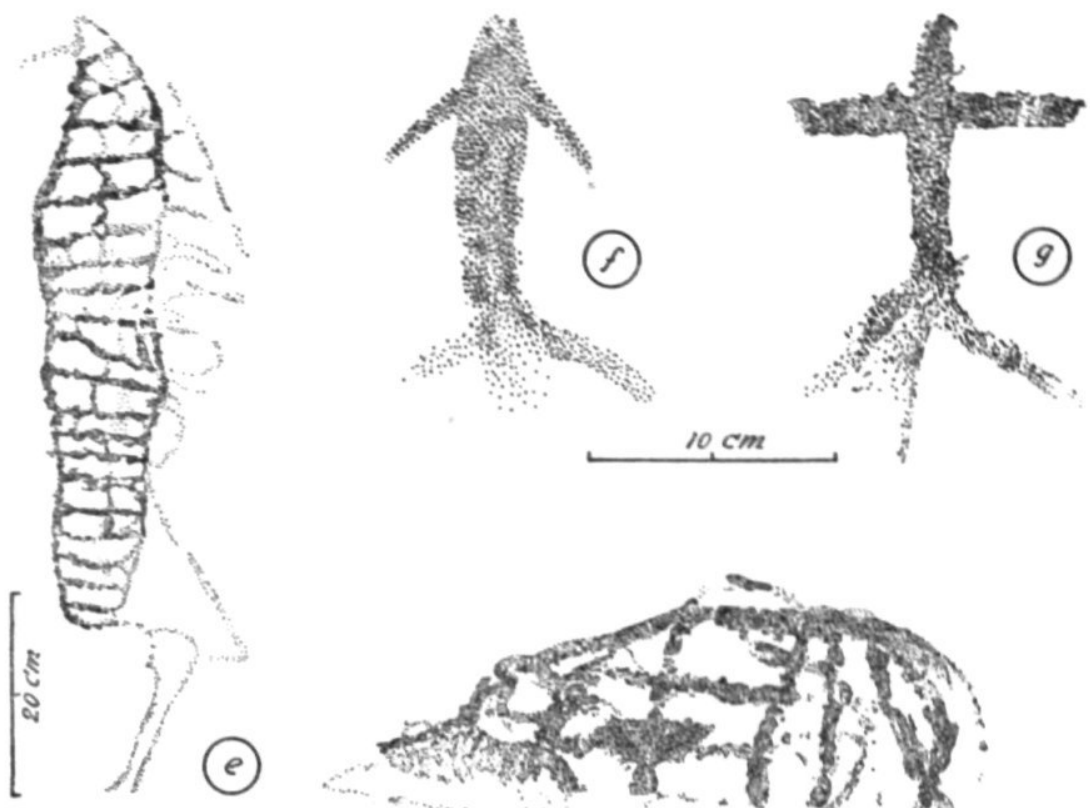

(e)

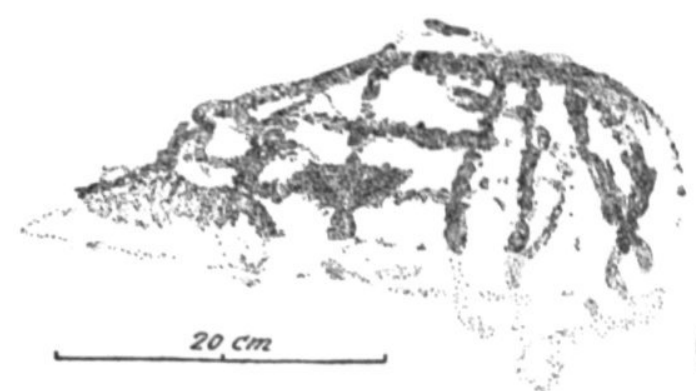

(m)

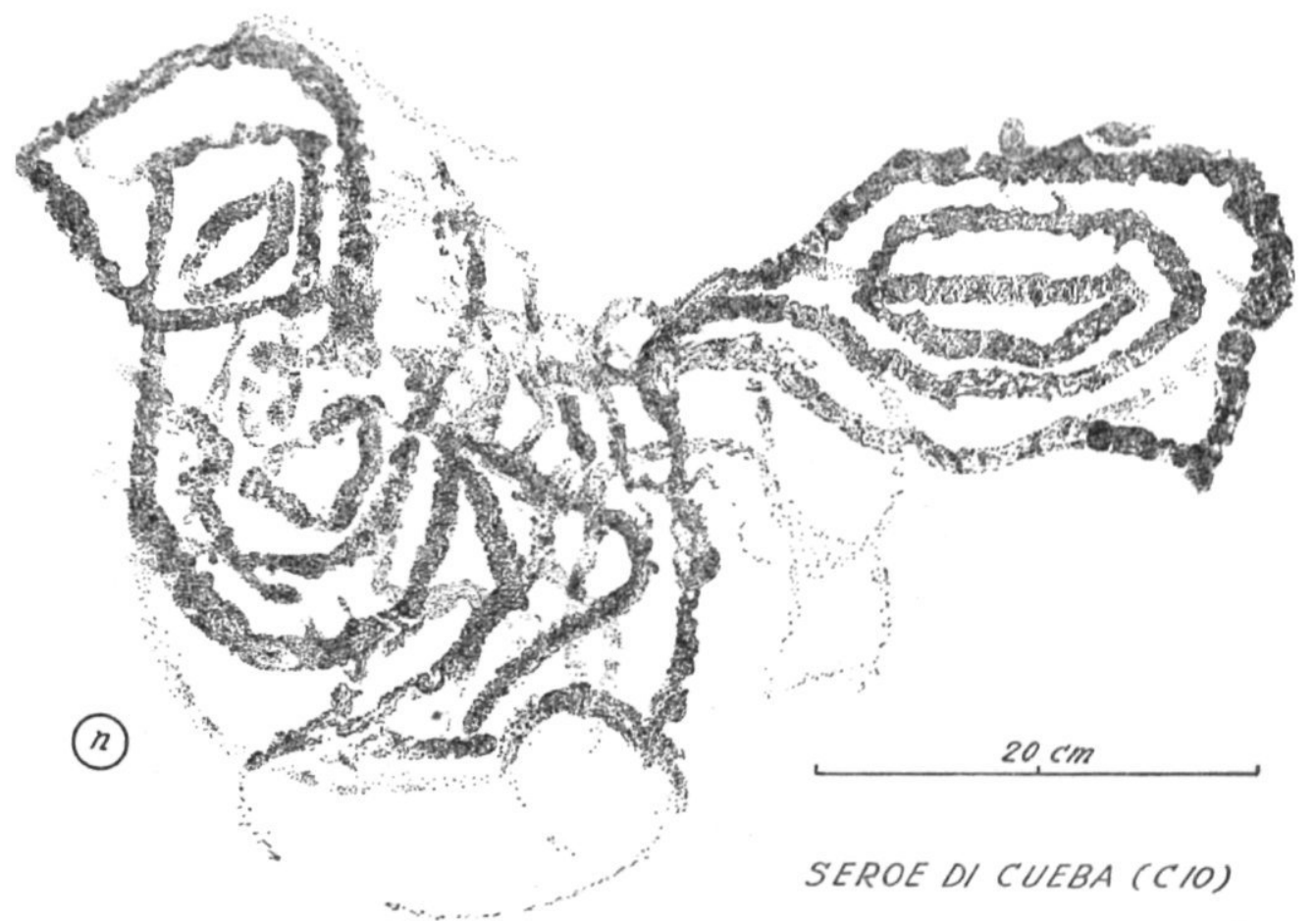

Fig. 24. Enkele van de figuren van de Seroe di Cueba (C 10), Curaf̧a, zoals zij door de schrijver, ten dele met behulp van foto's werden getekend. Fig. 24. Some of the figures of the Seroes di Cueba (C 10), Curaçao, as drawn by the author, partly from photographs. 
De hier gevonden figuren - van welk bestaan enkele padvinders, die tezamen met dr W. G. N. vaN DER SLEEN deze vindplaats in 1932 bezochten, op de hoogte schijnen te zijn geweest - vormden tot voor kort de enige groep van rotsschilderingen welke van Curaçao bekend was. De vindplaats werd schrijver dezes op 3 April 1948 door de heer A. LEAvER, Directeur van de ,Mijnmaatschappij Curaçao”, getoond; zij is later door Ringma nog nader onderzocht.

Een groot rotsblok, beneden aan de helling, vertoont nog enkele onduidelijke sporen van een roodachtige tekening; verder werd in deze omgeving niets meer gevonden.

De onvolprezen Noordkust: een smalle kustvlakte waarover eens de branding werd gejaagd tot haar golven uiteenspatten tegen de steile rand van het kalksteenterras, of doodliepen in de boca's welke zich aan de mondingen der rooien hadden gevormd.

Evenals dit thans nog geschiedt, werd ook toen - op plaatsen waar niet te grote golven lange tijd achtereen tegen de rotsen slaan - een z.g. brandingsnis gevormd, welke de kalksteenwand ter hoogte van de waterlijn ondermijnde. Toen - bij een latere rijzing van het land ten opzichte van de waterspiegel - de bodem van het ondiepe kustplateau boven water kwam, werden de brandingsnissen (vgl. fig. 1) de getuigen van gebeurtenissen uit lang vervlogen tijden.

Niet alleen kunnen wij uit de vorm en de ligging van de brandingsnissen van allerlei afleiden over het karakter van het kustwater dat dezen vormde, zij zijn in zekere zin ó́b het boek, waaruit wij iets te weten kunnen komen van voorhistorische culturen op de eilanden. De abris van Onima (B 1-4) spreken wellicht van een vrij wilde en onrustige zee; de smalle en diepe nissen van Hato (C 3, 8-9; fig. 6-8) en van de Seroe di Cueba (C 10; fig. 8) van golven die door hun loop over een ondiepe kustplateau reeds hun grootste kracht hadden verloren. De grot van Fontein (A 1) en Spelonk (B 6) zijn holen - door de vorming van de steile terrasrand ontsloten - waarvan de ingang door de zee tot een breed gewelf is verwijd.

\section{(C 2) Ronde Klip (fig. 6, 16)}

In de wand van het midden-terras op Ronde Klip, vlak bij de oostgrens van de plantage, bevindt zich een vrij diepe grot, waarin - door een achteringang en twee vensters in het plafond - zoveel licht naar binnen valt, dat zij zonder kunstlicht kan worden onderzocht.

Het is een luchtige ruimte welke een bijna volkomen beschutting biedt tegen het weer. De bodem is vlak en grotendeels bedekt met een laagje zachte grond. Voor de ingang liggen enkele grote kalksteenblokken welke het uitzicht belemmeren, maar de toegang niet belangrijk bemoeilijken. Het terrein ervoor is goede landbouwgrond en in het regenseizoen beplant met kleine mais.

Op de zoldering van de grotingang kunnen nog een negental figuren in een roodbruine kleurstof worden waargenomen, kennelijk de resten van een ingewikkeld en veel uitgebreidere beschildering (fig. 16). Andere sporen van deze vroegere bewonig werden niet aangetroffen.

Deze vind plaats werd door $A . D$. Ringma ontdekt en nader onderzocht in Juni 1951. 
(C 3) Hato (fig. 6, 18)

Ten Noordwesten van de Seroe Fortuna, ruim 2 kilometer ten Oosten van het landhuis Hato, is een brandingsnis van 2 meter diep en nauwelijks $1 \frac{1}{2}$ meter hoog. Er is een hoge drempel, welke dit abri maakt tot een nauwe en ondiepe schuilplaats, slechts matig beschuttend tegen regen, maar open naar het Noorden en dus fris, en in de schaduw van de middagzon.

Op het plafond van deze nis werden zeer vage resten van een roodbruine tekening aangetroffen, met daarbij nog een tiental vlekken, welke waarschijnlijk deel uitmaakten van een beschildering welke nagenoeg het gehele beschikbare oppervlak bedekte.

Een dertig meter ten Westen van deze plaats werden op de zoldering van dezelfde nis nog een viertal vage fragmenten gevonden.

Deze vindplaats werd door A. D. Ringma in Maart 1950 ontdekt.

$$
\text { (C 4) Hato (fig. 18-21) }
$$

Ruim 200 meter ten Oosten van de ingang van de Grot van Hato bevinden zich twee, naast elkaar gelegen, ondiepe abris aan de voet van het hoogterras (het middenterras is ter plaatse niet aanwezig).

De wanden vertonen enkele roodachtige vlekken, welke wel mogen worden beschouwd als resten van tekeningen. Slechts één motief - opvallend duidelijk en gaaf - is in de Oostelijke schuilplaats behouden gebleven (fig. 18).

In de westelijke abri onderscheiden wij, tegen de vrijwel loodrechte wand, enkele onduidelijke, in de ruwe kalksteen gehakte figuren, (fig. 20-21) (welke niet alleen zeer oud en verweerd schijnen te zijn, maar bovendien de indruk maken van niet te zijn vervaardigd door hen die wij voor de bruinrode tekeningen verantwoordelijk stellen. Opvallend voor de hedendaagse beschouwer is in elk geval, dat men hier ingewikkelde figuren als een gelaat met hoofdtooi (C $4 \alpha$ ) en een gecompliceerd ornament $(\gamma)$ vindt gehouwen in kalksteen welke zeer ongelijk van oppervlakte is en weinig gelijkmatig van structuur — op een plaats dus welke men thans stellig niet zonder noodzaak voor het maken van reliefs zou hebben uitgekozen.

Dit zijn de eerste in steen gehouwen tekeningen welke de schrijver tot nu toe van de Nederlandse Antillen bekend zijn, met C $4 \alpha$ als enig hem bekend, vrij duidelijk mensenbeeld - al moeten wij verdacht zijn op een sterke stylering van de menselijke gestalte, waardoor deze wel eens vormen zou kunnen aannemen zoals fig. C $10 f-g$, A $5 i, o-p$, A $3 a$ en B 5 $a, c$ ons vertonen.

Deze vindplaats werd door A. D. Ringma in Juli 1949 ontdekt en door de schrijver op 11 Augustus bezocht. De resulttaen van de opgravingen welke Ringma enkele maanden later verrichtte doen vermoeden dat deze plaats, dicht bij de bronnen van Hato, in het leven van de oude bewoners van Curaçao ook verder nog een zekere betekenis had.

(G 5-6) Rooi Rincon (fig. 7, 18-19)

Aan de Westzijde van de rooi, 450 meter van de windmolen van Boca Rincón, vinden wij een abri (C 5) van 3 tot 5 meter hoog en tot 12 meter diep, dat een goede beschutting geeft tegen zonneschijn en een vrij goede bescherming tegen regenbuien. De bodem bestaat grotendeels uit schelpen en andere resten van een herhaald verblijf der oude bewoners.

West-Indische Gids XXXIV 

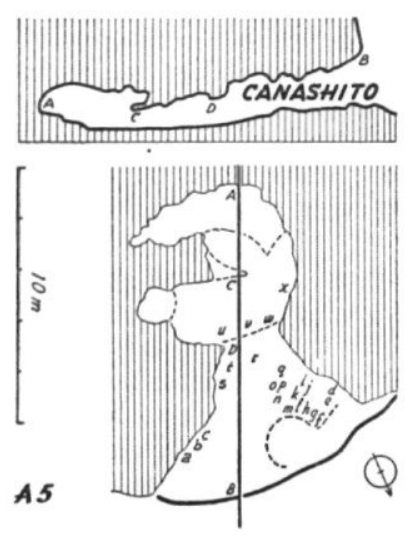

Fig. 25. Platte grond en doorsnede van de vindplaats in de grot van de Seroe Canashito (A 5), Aruba. - Voor de verklaring zie fig. 6.

Fig. 25. Ground plan and cross section of a cave in the Seroe Canashito (A 5), Aruba; finding place of many petrographs.
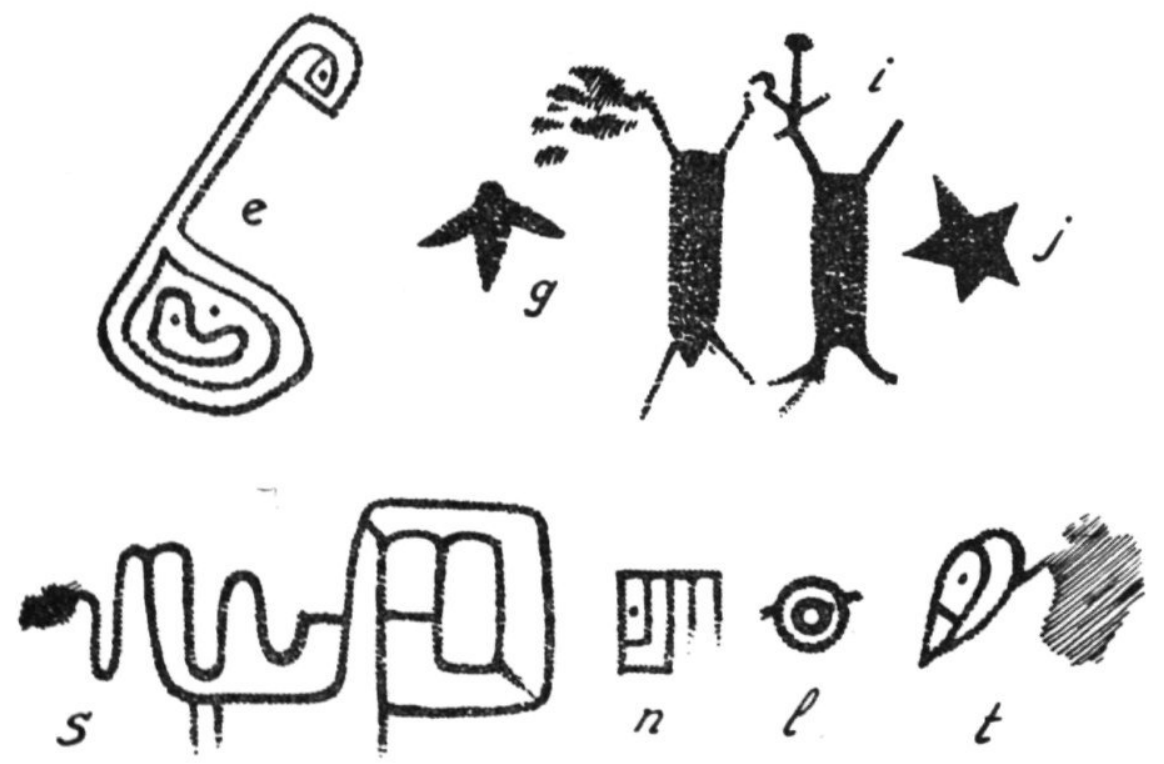

Fig. 26. Enkele rotstekeningen van een bruinachtig rode kleur uit een grot in de Seroe Canashito (A 5), Aruba, zoals zij door Martin, in 1885 en 1888 , werden afgebeeld.

Fig. 26. Some figures in red of a small cave in the Seroe Canashito (A 5), Aruba, as copied from Martin, 1885 and 1888. 


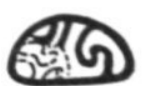

(a)

(b)

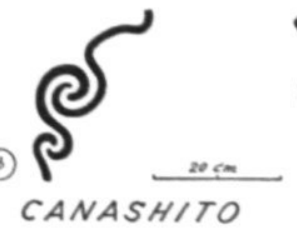

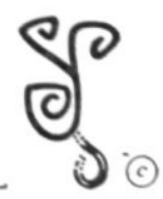

(A 4)
ㄴ?

()

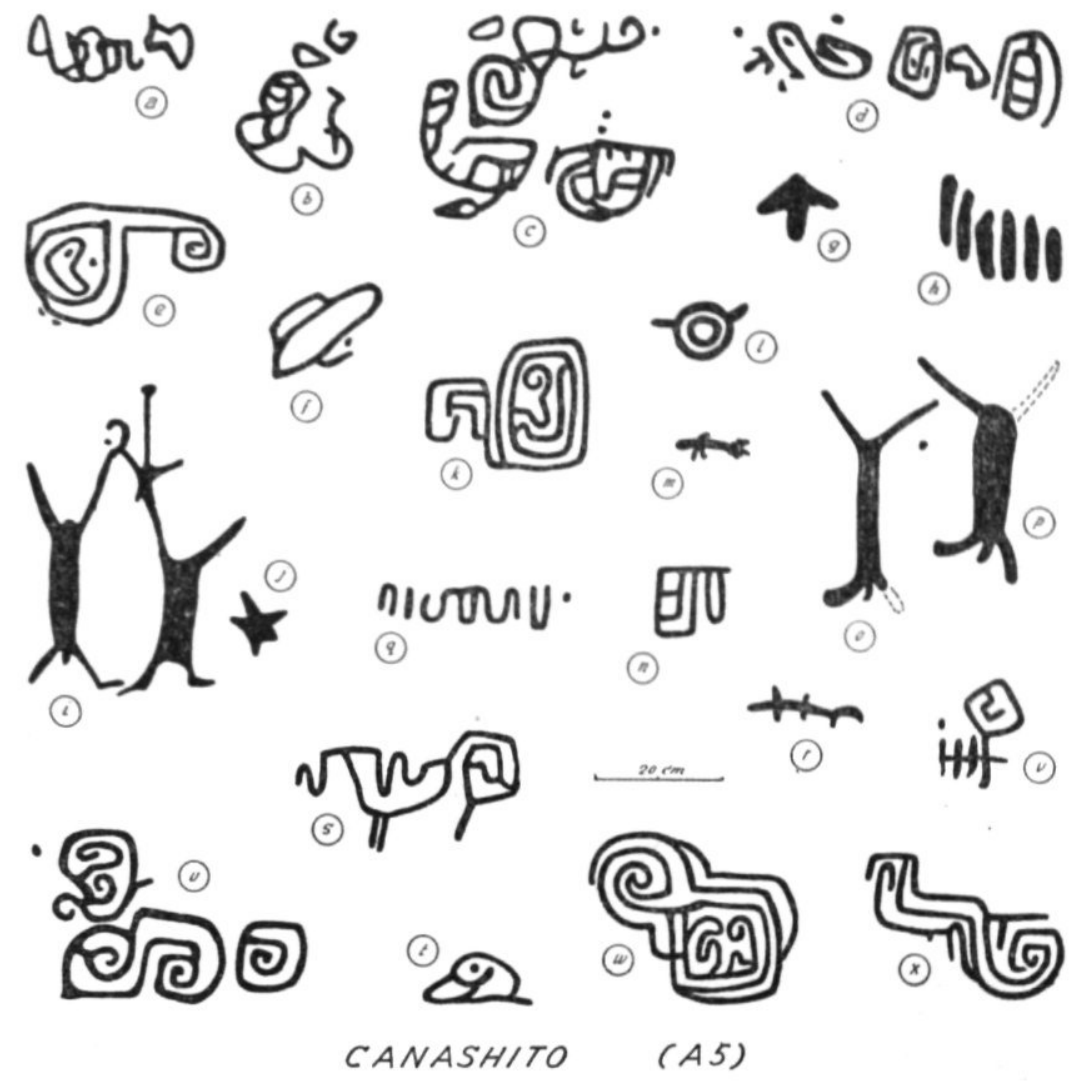

Fig. 27. Rotstekeningen uit twee kleine grotten van de Seroe Canshito (A 4-5), Aruba, uitgevoerd in een bruinachtig rode kleur, zoals zij door A. D. Ringma (van A 5) en de schrijver (van A 4) werden nagetekend. - De figuren A $5 g$ en $j$ lijken op een vogel en een ster; $l$ wordt door sommige personen het vliegende wiel genoemd, $n$ het telraam, $i$ de tweelingen.

Fig. 27. Rock drawmgs of two small caves in the Seroe Canashito (A 4-5), Aruba, made in red, as drawn in the field by Ringma (A 5) and the author (A 4). - A $5 g$ and $j$ are commonly identified with a bird and a star; $l$ is more rarely called a flying wheel, $n$ a bead-frame, $i$ twins. 


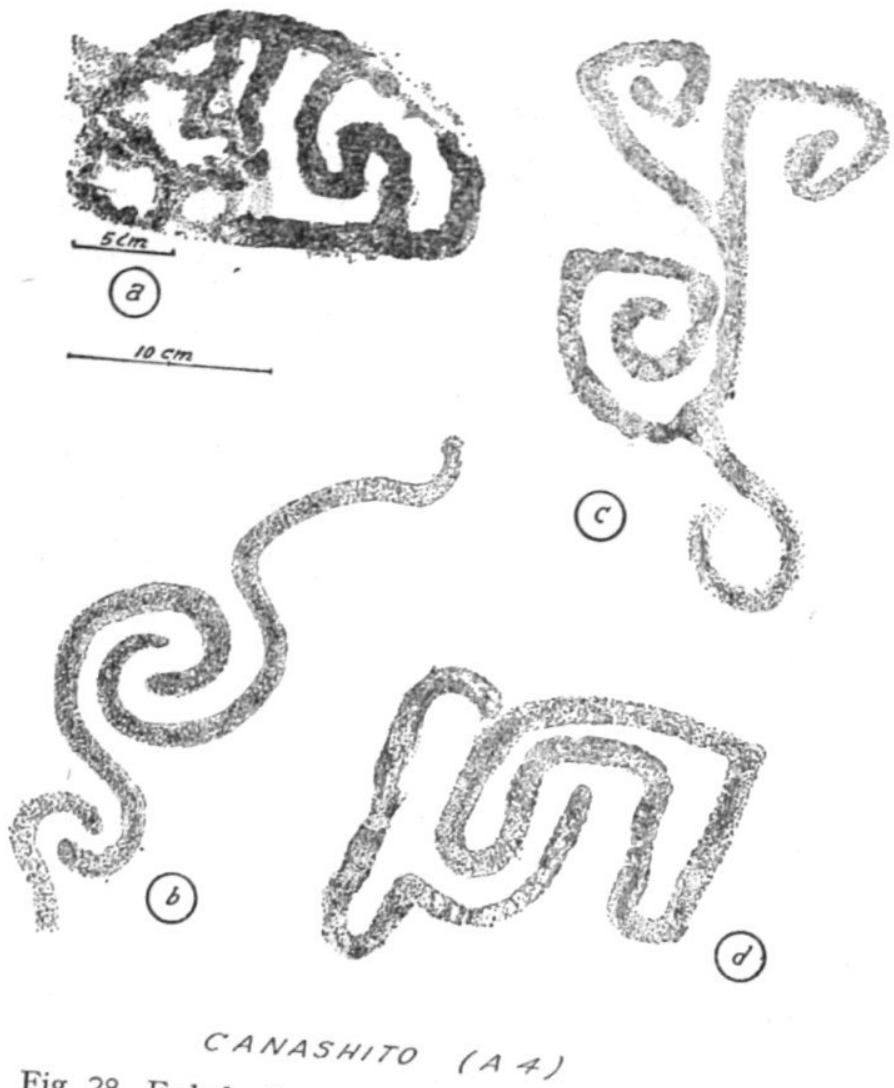

Fig. 28. Enkele figuren $(A$ )

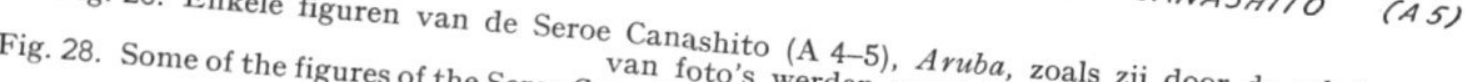

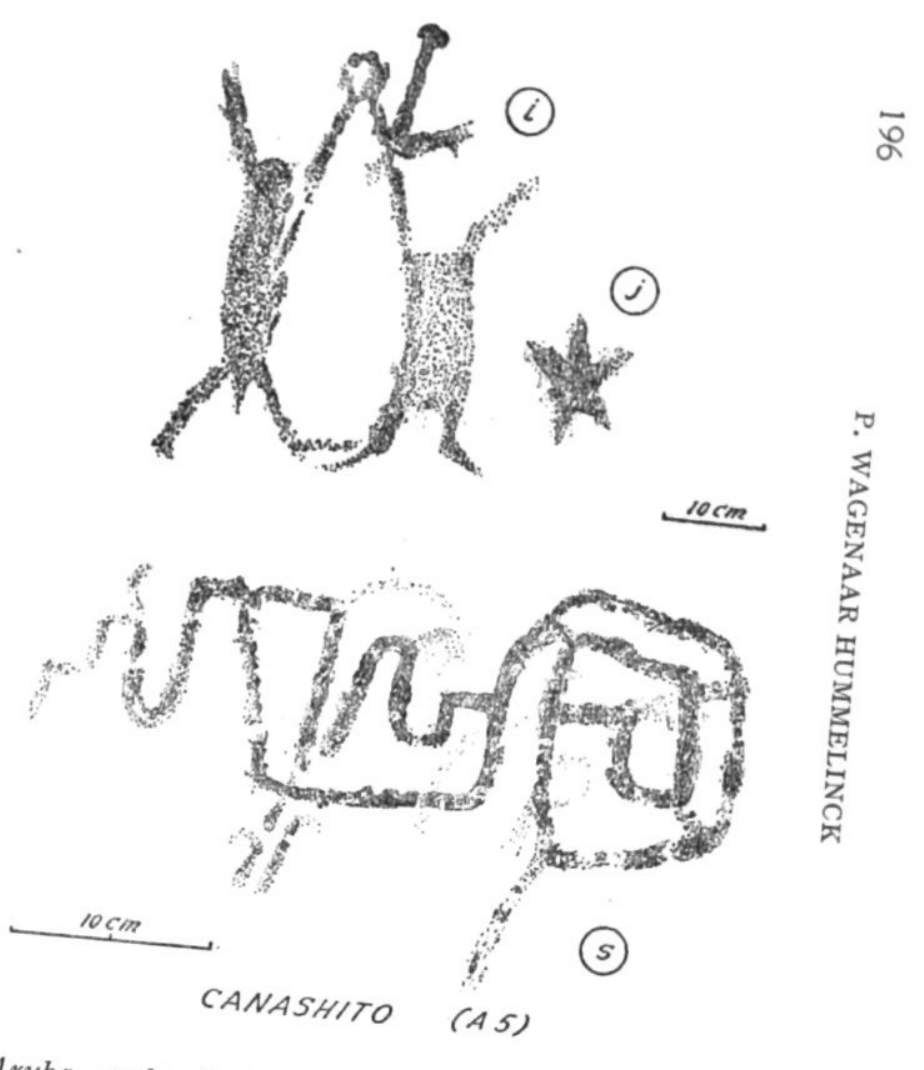



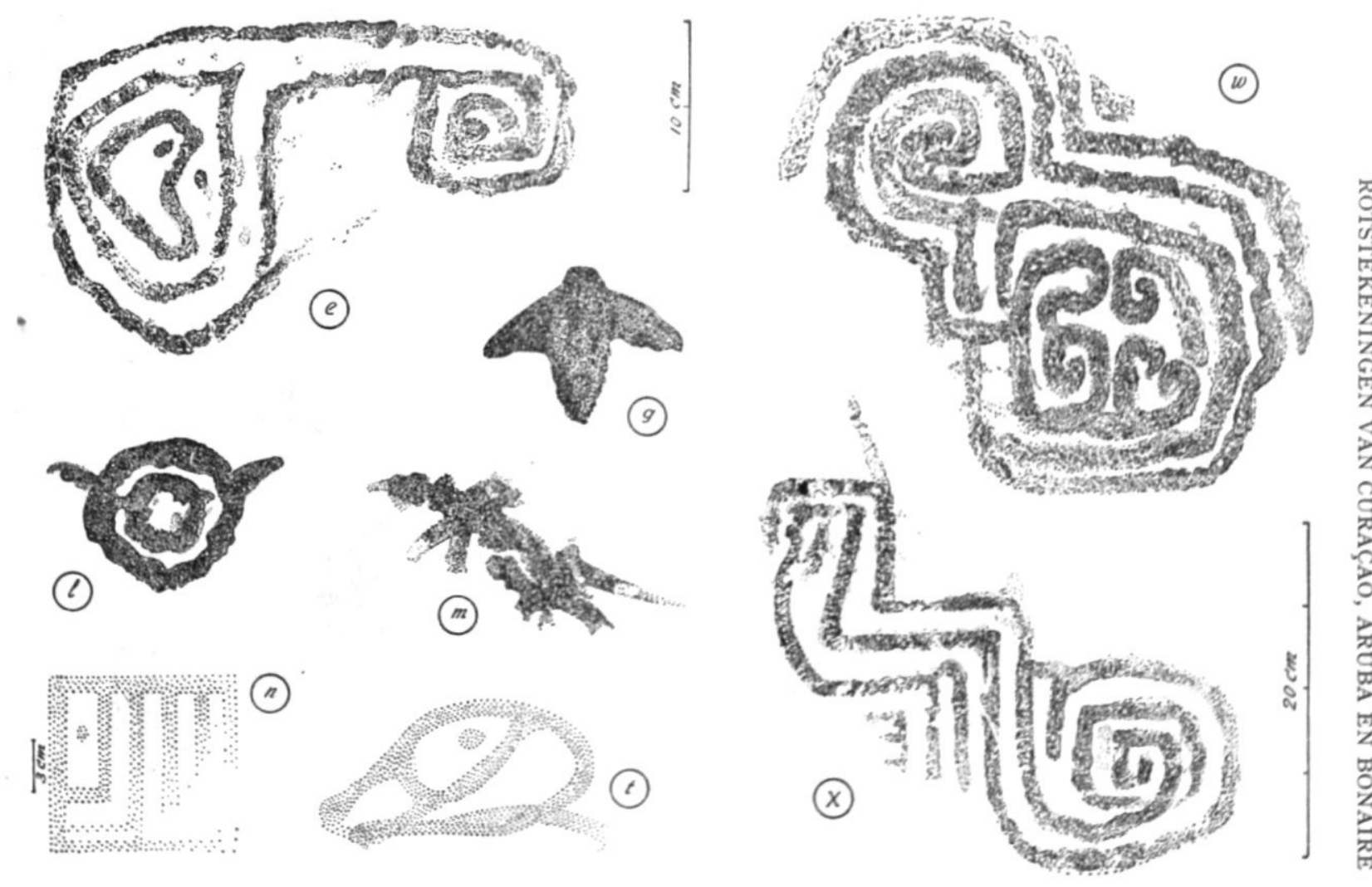

CANASHITO (A5)

CANASHITO (A 5)

Fig. 29. Enkele figuren van de Seroe Canashito (A 5), Aruba, zoals zij door de schrijver, voor een deel Fig. 29.

the Seroe Canashito (A 5), Aruba, as drawn by the author, partly from photographs. 


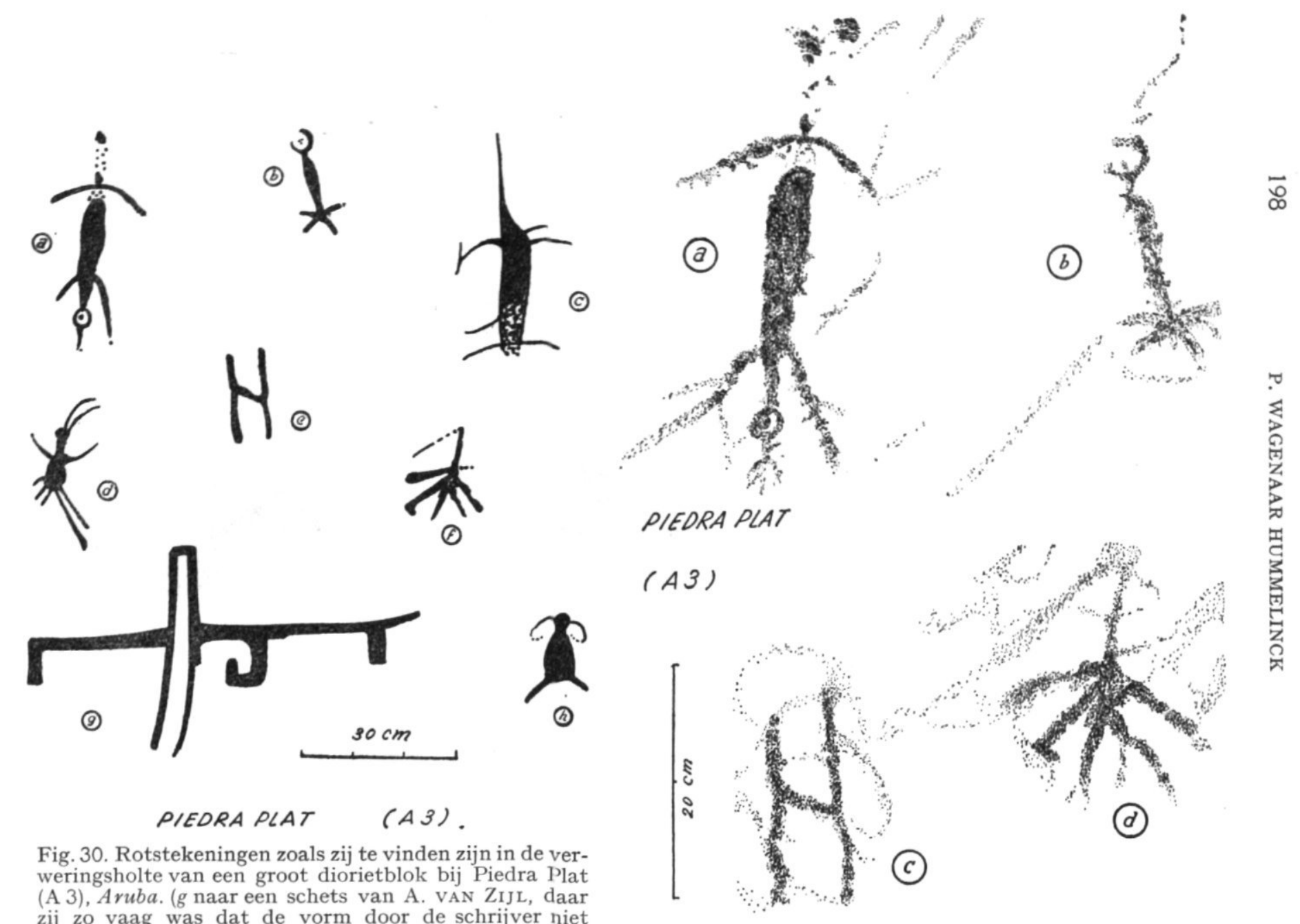

iij zo vaag was dat de vorm door de schrijver niet

Fig. 30. Petrographs in red of a small cave in a quartzdiorite monolith at Piedra Plat (A 3), Aruba.

Fig. 31. Enkele tekeningen van Piedra Plat (A 3), Aruba, zoals zij van twee foto's werden nagetekend.
Fig. 31. Some of the figures of Piedra Plat (A 3), A ruba, ( $g$ very indistinct). 


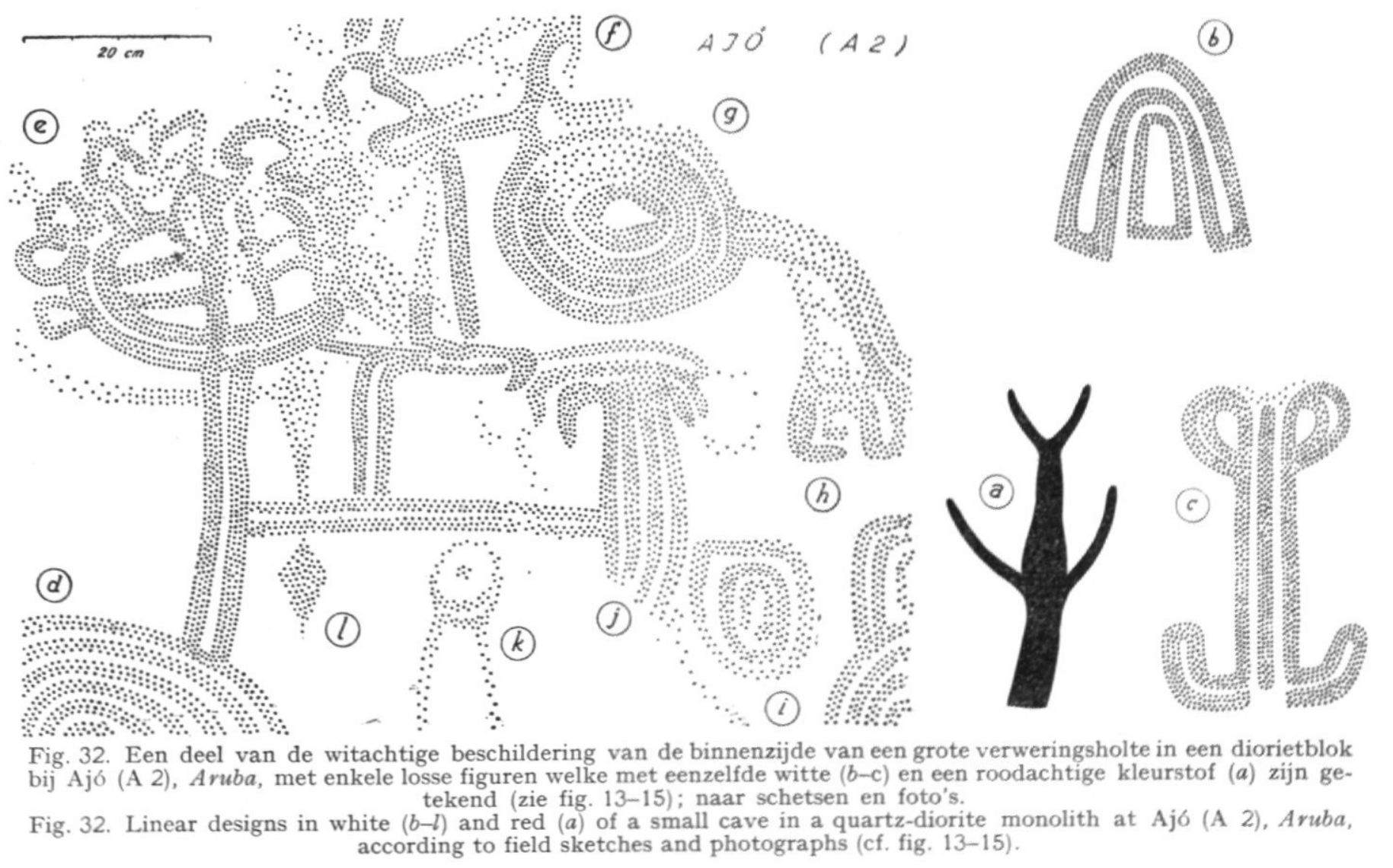


Roodbruine vlekken op een zestal plaatsen op de zoldering moeten waarschijnlijk verklaard worden als resten van een beschildering. Opmerkelijk is dat de kleurstof ver buiten het bereik van de hedendaagse bezoeker - tot 3 meter boven de begane grond - is aangebracht.

Bijna 100 meter zuidelijk van deze vindplaats vinden wij — merkwaardigerwijze op een naar het Oosten vooruitstekend stuk kalksteen (C 6), bijna $1 \frac{1}{2}$ meter boven de grond, de overblijfselen van een roodbruine tekening (fig. 18-19).

De rotsen bieden hier geen schuilplaats, en andere sporen van een vroeger verblijf zijn hier dan ook niet te vinden.

Deze vindplaatsen werden door A. D. Ringma in Juli 1949 gevonden, door de schrijver op 11 Augustus bezichtigd, en door de ontdekker in December van hetzelfde jaar nader onderzocht.

$$
\text { (C 7-9) Hato (fig. 7-8, } 16 \text { 18-19) }
$$

Twee honderd en vijftig meter ten Westen van het begin van het middenterras van Hato zien wij, op het plafond van een brandingsnis (C 7), enkele bruinrode tekeningen (fig. 18-19), alsmede een aantal vegen van dezelfde kleur. $\mathrm{Zij}$ bevinden zich op ongeveer 3 meter hoogte en zouden al kruipende door het hooggelegen, diepste deel der nis kunnen zijn aangebracht.

De bodem ligt gelijk met het terrein er voor en bestaat uit losse grond.

Bijna een kilometer verder naar het Noordwesten vinden wij, onder dezelfde omstandigheden (C 8), een fragment van een grote tekening in een roodbruine kleurstof (fig. 16).

Nog verder naar het Noordwesten - ter hoogte van het sport-landingsterrein bij San Pedro, op ongeveer $1 \mathrm{~km}$ afstand van de brakwatergrot van Sjingod - vormt de brandingsnis een goed toegankelijk abri, (C 9) met de opening aan de windzijde, waar men beschut staat tegen regen en middagzon.

Op de zoldering staan hier, op 11 1 -2 meter hoogte, enkele resten van roodbruine tekeningen (fig. 16) met nog een aantal vegen.

De bodem van de nis, evenals het terrein er vlak voor, is - als bij de vorige vindplaats - steenachtig.

$\mathrm{Bij}$ geen van deze vindplaatsen werden andere tekenen van een verblijf van vroegere eilandbewoners gevonden.

Deze drie vindplaatsen werden door A. D. Ringma achtereenvolgens in November 1949, Februari 1950 en Mei 1950 ontdekt.

(C 10) Seroe di Cueba (fig. 8, 10, 22-24)

Onder de noordelijke middenterrasrand van de Seroe di Cueba, 200 meter ten Westen van de ingang van de Cueba Bosà op de plantage Savonet, werd vrij zachte kalksteen een diepe brandingsnis gevormd, welke de meest opvallende collectie rotstekeningen bevat die tot nu toe op Curaçao is aangetroffen.

Deze abri is omstreeks 25 meter lang, 5-12 meter diep en slechts meter hoog. $\mathrm{Zij}$ is goed toegankelijk; de opening is de windzijde toegekeerd en men zit er goed beschut tegen zon en regen. De bodem is nogal hard; op enkele plaatsen zijn er inactieve druipsteenafzettingen, en bij regen sijpelt er op verschillende plaatsen water door het dak.

Op het niet bijzonder gladde plafond vinden wij hier een twintigtal, 
merendeels duidelijke maar vrij slordig getekende figuren, met nog talrijke fragmenten en vegen, in een bruinachtig rode kleurstof. Opvallend is hierbij een ",vis"-motief (fig. 22, C $10 a, b, k$ ), terwijl andere figuren (fig. 22 en $24, m, n$ ) aan een vogel en een varken doen denken - een gelijkenis welke op toeval berust (fig. 23).

Er zijn geen aanduidingen gevonden welke er op wijzen dat deze plaats vroeger bewoond zou zijn geweest.

Deze tekeningen werden begin April 1949 door A. D. Ringma gevonden, nadat bij geruchte was vernomen dat er bij de Seroe di Cueba indianentekeningen voorkwamen. De vindplaats werd op 15 April door de schrijver, in gezelschap van enkele leden van de „Werkgroep", bezocht en door Ringma in Maart 1950 nader bestudeerd.

\section{BESCHRIJVING VAN DE VINDPLAATSEN OP ARUBA}

In de o mgeving $\mathrm{v}$ a $\mathrm{n} \mathrm{S}$ an $\mathrm{ta} \mathrm{Cruz}$ liggen - als resultaat van de hoofdzakelijk physische verwering van het gesteente en het daarop volgende wegvoeren van het losse materiaal - grote en kleine hopen van afgeronde diorietblokken over het vlakke landschap vers preid (vgl. fig. 2). De grootste opeenhopingen vinden wij bij Ajó: deze zijn 20-30 meter hoog en bestaan uit blokken welke vaak een middellijn van 5-10 meter bereiken.

Vele van deze blokken, zg. monoliethen, van West Aruba vertonen zeer opvallende ronde holten, van enige centimeters tot enkele meters in doorsnede, meestal in de zuidwestelijke wand, dikwijls ook aan de zuidzijde of aan de westkant. Deze holten - waarvan vaN Koolwijk (1882, p. 5) en MARTiN (1888 I, p. 124) dachten dat zij door de branding van de zee waren ontstaan - zijn toe te schrijven aan een vorm van physische verwering welke heden ten dage nog actief is (W. I. Gids 2o, 1938, p. 364)

Enkele van deze holten hebben stellig de vroegere bewoners van het eiland tot schuilplaats gediend, zoals zij heden ten dage nog dienen als onderkomen voor geiten bij ongunstige weersomstandigheden. Oude rotstekeningen op de wanden van deze ruimten wijzen wellicht op een nog belangrijker functie in hun samenleving.

$$
\text { (A 2) Ajó (fig. 14-15, 32, 36) }
$$

Dicht bij het huis van Marcello Kelly, te Ajó, ligt een kwartsdiorietblok met een uitholling van ongeveer 5 meter breed en 4 meter diep, welke een ruime ingang heeft op het Zuidwesten. De hoogte van het gewelf is thans 1,80 meter; de bodem bestaat uit losse grond met veel geitenmest.

Een groot deel van de wand is beschilderd met witachtige en bruinachtig rode figuren. De eerste indruk is, dat de witte figuren - die het duidelijkste zijn — over de rode heen zijn geschilderd; op enkele plaatsen (fig. 13) was echter te zien hoe de rode kleurstof welke op de witte was aangebracht, hierop gemakkelijker loslaat dan wanneer zij direct op de steen was gesmeerd.

Een ander deel van de wand heeft geen tekeningen; zij lijkt vers afgeschilferd. Volgens Marcello Kelly - die mij deze vindplaats op 18 Jan. 1949 toonde - stonden hierop vroeger vele mooie figuren, waar- 


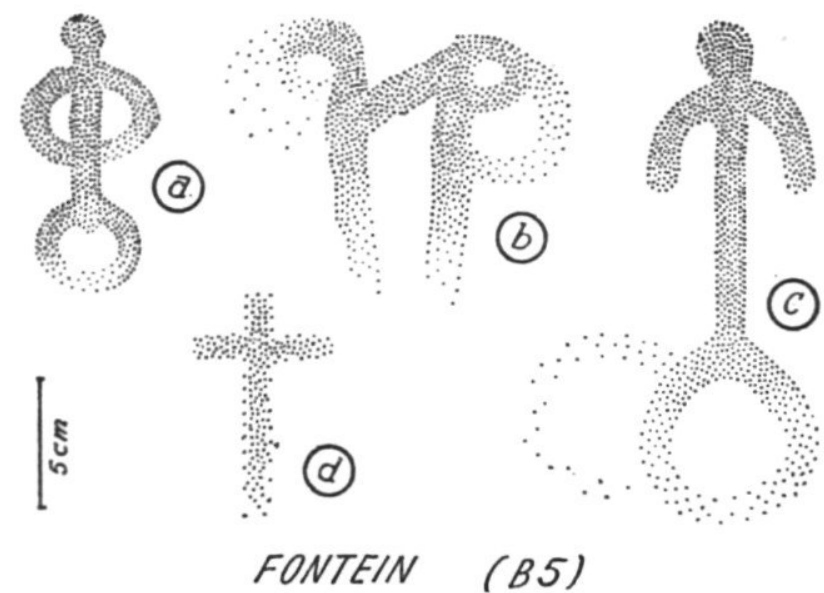

Fig. 33. Rode figuren op een kalksteenblok, de Piedra di Compafuru, bij Fontein (B 5), Bonaire, volgens veldschetsen.

Fig. 33. Red figures on a limestone block near Fontein (B 5), Bonaire, according to field sketches.

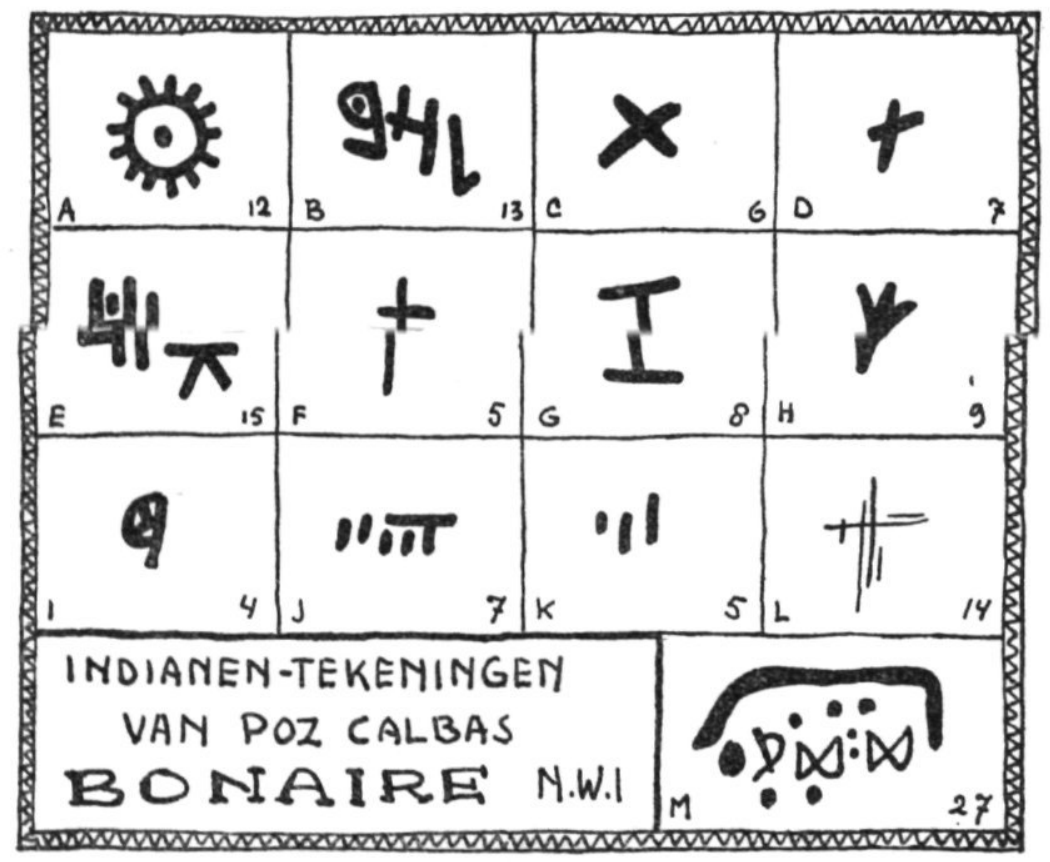

Fig. 34. De rode tekens bij de ingang van de grot van Pos Calbas, Lima (B 7), Bonaire, zoals zij werden afgebeeld door Pater BRENNEKER, 1944. ,,Het cijfer rechts onderaan in ieder hokje geeft de breedte der figuren aan, d.w.z. de afstand van de verticale lijnen, die de tekening links en rechts raken". Grootste afmetingen welke werden opgegeven door L. D. Gerharts: A $10 \mathrm{~cm}, \mathrm{~B} 12 \frac{1}{2} \mathrm{~cm}, \mathrm{E} 16 \frac{1}{2} \mathrm{~cm}, \mathrm{H} 11 \frac{1}{2} \mathrm{~cm}, \mathrm{M} 26 \mathrm{~cm}$. Fig. 34. Red characters on the coral rock of Pos Calbas (B 7), Bonaire, as given by father BRENNEKER, 1944, with measurements in $\mathrm{cm}$. 
onder een vis. Het is duidelijk dat door een aanraken van de wand sommige tekeningen gemakkelijk kunnen worden beschadigd, of zelfs verloren kunnen gaan.

\section{(A 3) Piedra Plat (fig. 30-31)}

Bezuiden het kerkje van Piedra Plat ligt een blok kwartsdioriet met, op het Westen, een naar verhouding enorme holte van ongeveer 3 meter in doorsnede. Het blok lijkt enigszins voorovergevallen en is ten dele gespleten. Het resultaat is een ruimte, met een vrij lage ingang, welke een uitstekende beschutting biedt tegen regen en wind, en om deze reden kennelijk veel door geiten wordt bezocht.

De vrij ruwe wand vertoont enkele tekeningen, waarvan een - ook van andere vindplaatsen bekende - pijlvormige figuur (A $3 a$ ) door het afvallen van steenschilfers nogal is beschadigd. Een groot ornament $(g)$ bleek zo onduidelijk, dat het niet door de schrijver kon worden waargenomen; het werd nagetekend door J. vaN $\mathrm{Z}_{\mathrm{IJL}}$, met wie deze vindplaats op 15 Januari 1949 werd bezocht.

De Seroe Canas hito, die - als rest van een kalksteenkap welke vroeger een groot deel van West Aruba bedekte - in de richting van de Hooiberg oprijst en aan landzijde steil afbreekt, is stellig een van de meest belangwekkende plekjes van Aruba. VAN Koolwij K heeft ons van zijn exploratie van de steile Noord- en Oostrand van de "Carachito" zoveel merkwaardigheden verteld, dat er in dit gebied stellig nog heel wat meer is te vinden dan hieronder wordt medegedeeld.

$$
\text { (A 4-A 5) Seroe Canashito (fig. 11-12, 25-29) }
$$

Ongeveer 12 meter beneden de noordrand van de kalksteenheuvel, waar deze aan de westzijde betrekkelijk laag is - een dertigtal meters van de rand van de steengroeve welke voor deze vindplats een directe bedreiging vormt - ligt (in Januari 1949!) een kleine grot (A 4), slechts over een afstand van 6 meter begaanbaar, en dan laag wegduikend, evenwijdig aan de rotswand, waarin nog een paar kleine openingen aanwezig zijn.

Het bewoonbare deel van deze grot is slechts een drietal meters breed, diep en hoog. In het dak en de wanden bevinden zich oplossingsholten, en er zijn slechts enkele, weinig opvallende, inactieve druipsteenafzettingen.

Op een naar het Noorden gericht vlak, op hoogten van $1 \frac{1}{2}$ tot $2 \frac{1}{2}$ meter, vinden wij de motieven welke op fig. 11 en 28 staan afgebeeld. Er komen verder nog 6 andere ornamenten voor, waaronder 4 onduidelijke, op slechts een halve meter hoogte. De bruinrode tekeningen op deze plaats maken slechts voor een klein deel een min of meer verse indruk; het merendeel is als met een crêmekleurige laag overtrokken en bijna niet meer te zien.

Verder van de steengroeve af ligt, in dezelfde steile noordkant, 15-20 meter onder de top, een grotere grot (A 5), welke tot op meer dan 10 meter diepte bewoonbaar is. De bodem hiervan is rotsig, slechts hier en daar met poederachtige verweringsgrond bedekt.

De Indianentekeningen welke MARTIN van de "Carachito" afbeeldt 
(fig. 26) bevinden zich in dit hol. Het geheel maakt de indruk, niet te zijn veranderd sinds het bezoek van deze grote natuuronderzoeker in 1885! De meeste tekeningen liggen in het deel, dat ongeveer 5 meter breed en diep is, en $2 \frac{1}{2}$ meter hoog; slechts een enkele vinden wij in het achterste, lagere deel, tegen de wand (A5 $x$ ) en tegen het plafond boven de ingang $(u-w)$.

De helling van de heuvel is bestrooid met schelpen, geconcentreerd in de buurt van enkele abris en van enige blokken aan de voet.

Beide grotten werden door de schrijver bezocht op 14 Jan. 1949; de tweede ook door Ringma in Nov. 1950.

\section{BEschriJving van DE vindPLAATSEN OP BoNAIRE}

De Noordkust van Bonaire is een gebied dat in velerlei opzicht vergelijkbaar is met de Noordkust van Curaçao. Het is ook, evenals deze, een terrein dat in archaeologisch opzicht grondig dient te worden onderzocht, vooral in verband met de reeds lang bekende, belangrijke vindplaatsen van rotstekeningen bij Onima (B 1-4) en Spelonk (B 6).

(B 5) Fontein (fig. 33)

Vier honderd meter ten westen van het hek van de Plantage Fontein, ligt een eenzaam, van het hoogterras afgestort kalksteenblok, van ongeveer 15 bij 10 bij 5 meter.

Op zijn westelijke zijde, op $1 \frac{1}{2}$ meter hoogte, draagt dit rotsblok enkele bruinrode tekeningen (fig. 33).

Volgens F. C. A. ChIRINo, die mij deze vindplaats op 3 September 1949 wees, is deze steen bij de bevolking bekend als de ,"Piedra di Compafuru”

Ongeveer 25 meter de helling, op vinden wij voorts nog enkele onduidelijke, elkaar onder rechte hoeken snijdende, rode lijnen, op een vlakke kalksteenwand.

Z u i d B o n a i r e bestaat uit een vlak, laag kalksteenplateau. Door instortingen, en in spleten, wordt op talrijke plaatsen het grondwater ontsloten, dat op een diepte van ten hoogste $3 \frac{1}{2}$ meter in een min of meer samenhangend systeem van holten en spleten aanwezig is.

\section{(B 7) Pos Calbas (fig. 13, 34-35)}

Aan de noordwestzijde van een ingestort deel van het kalksteenplateau - nabij de noordgrens van de plantage Lima, ten Ziuden van de oosthoek van het vliegveld - bevindt zich een met drinkbaar water gevulde grot, welke zich na een twintigtal meters in een netwerk van met water gevulde holten onder het plateau verliest. In 1948 werd op de grot een molen geplaatst en een transportleiding aangelegd naar Kralendijk welke gedurende enkele maanden gemiddeld $120 \mathrm{~m}^{3}$ water per dag leverde. De ingang van de grot werd toen met gaas afgesloten.

Hoewel kan worden aangenomen, dat de bevolking ook in vroegere tijden haar drinkwater voor een deel uit de putten, welke zich in deze buurt bevinden, betrok, was het toch een verrassing, toen pater Virus BRENNEKER O. P. in 1944 een aantal rotstekeningen afbeelde (fig. 34) welke hij op deze plaats had gevonden. De ontdekker schrijft over deze 
merktekens, die, weinig opvallend, op zeer ruwe koraalrots zijn aangebracht: ,, Bij de ingang van de grot, rechts, vinden wij op de schuin aflopende wanden .... echte Indianentekeningen. De meeste zijn nog in zeer gave toestand. Wij tellen er in het geheel 24 , waarvan wij de dertien allerduidelijkste hierbij [vgl fig. 35] weergeven. .... Bijna alle zijn rood, evenals de andere tekeningen op Bonaire, en ook als met een penseel geverfd; het zijn brede strepen, zowat een pink dik. Alleen het kruis.... [i] maakt een uitzondering. Het is donkerder van kleur en als met een stift of kleurkrijtje getekend, in zeer dunne lijntjes. Al de overige zijn er - zo schijnt het althans - met een natte verfstof opgesmeerd. De zon (A), de kruisen (C. D. F.), en de gaffel (H) zagen wij elders op Bonaire, de overige niet."

Deze tekens werden door de schrijver-eerst op 8 Sept. 1948 gevonden, nadat zij, bij een vroeger bezoek aan Pos Calbas, aan zijn aandacht waren ontsnapt.

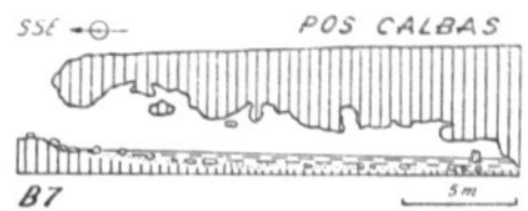

Fig. 35. Doorsnede in ZZO-NNW richting van de grot van Pos Calbas (B 7), op de plantage Lima, Bonaire. - De kalksteen is gearceerd, het water horizontaal gestreept.

Fig. 35. Cross section SSE-NNW of the water bearing limestone cave of Pos Calbas (B 7), Bonaire.

\section{LITERATUUR}

\section{REFERENCES}

Publicaties gemerkt met een * bevatten geen gegevens over rotstekeningen.

Publications marked with an * do not contain data on petrographs.

$\checkmark 1836$ Bosch, G. B.: Reizen in West-Indiē ... II. Utrecht. (p. 219220)

1837 Teenstra, M. D. : De Nederlandsche West-Indische Eilanden, II Amsterdam. (p. 200)

*(1880) Leemans: Antiquités américaines récemnent acquises pour le Musée Royal Néerlandais d'Antiquités à Leide. Compte Rendu 3 Congr. Americanistes, Bruxelles 1879, I, p. 657-675, tab. 1-16 excl. - Antiquités des îles, p. 659-673, tab. 2-15.

*1881 KoolwiJK, A. J. VAN: De Indianen-Caraïben, oorspronkelijke bewoners $\operatorname{van}$ Curaçao. Tijdschr. Aardrijksk. Genootschap 5 , p. 57-68.

$\sqrt{ } 1882$ KoolwiJk, A. J. VAN: De Indianen Caraỉben van het eiland Aruba (West-Indië). T. Aardr. Gen. 6, p. 222-229, tab. excl. (p. 225-226)

V1885 Martin, K.: De Nederlandsche expeditie naar de West-In- 
dische eilanden en Suriname 1884-1885. T. Ned. Aardr. Gen. (2) 2 Versl., p. 337-361, 448-487, 610-646. (p. 356)

1885 Martin, K.: Indianische Zeichnungen aus den Höhlen von Aruba .... Etudes archéologiques, linguistiques et historiques dédiées à $\mathrm{Mr}$. le Dr. C. Leemans, Leide, p. 180-182, tab. excl. First figures of petrographs from Aruba: Fontein and Canashito.

1885 Koolwijk, A. J. VAN: Indiaansche opschriften te Aruba. Études arch. Leemans, p. 183-184.

1888 Martin, K.: Bericht über eine Reise nach Niederländisch West-Indien ...I. Land und Leute. Leiden. Indianische Zeichnungen von Aruba, p. 133-135, tab. XIV; same figures as given in 1885 .

1890 Pinart, A. L.: Note sur les pétroglyphes et antiquités des Grandes et Petites Antilles. Paris, 17 pp. text: 15 pp. figg., fac-simile of Ms. - Referring to Aruba, p. 6.

1890 Pinart, A. L.: Aperçu sur l'ile d'Aruba, ses habitants, ses antiquités, ses pétroglyphes. Paris, fac-simile of Ms. $\left.{ }^{1}\right)-\mathrm{Re}-$ ferred to by Mallery, 1893; see also Josselin de Jong, 1918, p. 52.

1890 Pinart, AlPh.: Limite des civilisations dans l'isthme Américain. Pétroglyphes et notes anthropologiques. Paris, 18 pp., fac-simile of Ms. - Pétroglyphes dans l'Isthme Américain,... $3+\mathrm{pp}$. fig.; refers to Aruba.

? 1893 Mallery, Garrick: Picture-writing of the American Indians. Tenth Ann. Report Bureau Am. Ethnology, 1888-'89. Refers to Pinart, 1890 , p. 139-140.

*1904 Schmeltz, J. D. E.: Ứber Sammlungen aus Niederl. Westindien und Surinam. In: Beiträge zur Anthropologie, Ethnographie und Archaeologie Niederl. Westindiens (given to members of the 14th Int. Congr. of Americanists, Stuttgart), p. 1-7, tab. 5 (map) excl. Mittheilungen Niederl. Reichsmuseum für Völkerkunde, Veröffentl. Serie 2, no 9.

*1904 Leemans, C. : Altertümer von Curaçao, Bonaire und Aruba. In: Beitr. Anthr. Ethn. Arch. Niederl, Westindiens, p. 7-17, 17 figg., tab. 6-8 excl. Mitt. Niederl. Reichsmus. Völkerk. Veröff. (2) 9.

*1904 Koeze, G. A.: Schädel von Curaçao und Aruba. In: Beitr. Anthr. Ethn. Arch. Niederl. Westindiens, p. 18-22. Mitt. Niederl. Reichsmus. Völkerk. Veröff (2) 9 .

? 1907 Euwens, P. A.: Historisch overzicht van het eiland Bonaire. Neerlandia II (Bonaire-nummer, Dec. 1907), p. 193-197, 3 figg. (p. 194-195) - First figures of petrographs from Bonaire, as drawn by Van Koolwijk: Onima.

21911 Euwens, P. A.: Geschiedkundig overzicht van het eiland Aruba. Neerlandia I5 (Aruba-nummer, Dec. 1911), p. 265, 267-268.

21916 KATE, H. TEN : Oudheden. ,De W.I. Eilanden. In: Encyclopaedie van Nederlandsch West-Indië, 1914-1917, p. 543-546.

*1918 Josselin DE Jong, J. P. B. DE: The praecolumbian and early postcolumbian aboriginal population of Aruba, Curaçao and

1) Not seen by the author, who would highly appreciate any suggestion which would lead to the rediscovery of this paper. 
Bonaire. Intern. Archiv fur Ethnographie 24, p. 51-114, plate 15-30.

*1920 Josselin de Jong, J. P. B. DE: De beteekenis van het archaeologisch onderzoek op Aruba, Curaçao en Bonaire. W.I.Gids I, vol. 2, p. 317-334.

*1923 Josselin DE Jong, J. P. B. DE: The praecolumbian ... population of Aruba, Curaçao, and Bonaire. Intern. Archiv Ethn. 25 , p. 1-26. - Part I continued. Pottery. No more parts published. - See also T. Ned. Aardr. Gen. 1924, p. 356-357.

? 1929 Amelunxen, C. P.: De geschiedenis van Curafao. Priv. ed. (Nijhoff, The Hague). - Part of about the same figures given by Euwens, 1907. (p. 10)

1934 Wollebaek, Alf: Curaçao, Norsk Geogr. Tidsskr. 5, p. 95109, 9 figg. - Fig. 7 from Martin, 1888. (p. 106-109)

1938 WagenaAr Hummelinck, P.: De grotten van Curaçao, Aruba en Bonaire. In: Realino, De Nederlandse Antillen, p. 128-133, 4 figg. - Photographs of petrographs from Aruba: Fontein.

1943 Rings, Wm. Refus: Aruban Annals, ed. 4. Priv. ed., Plain City, Ohio, ii +37 pp., ill., mimeogr. - Rough sketches of petrographs from Aruba: Canashito. (p. 6)

1944 BRENNEKER, Vitus: Indianentekeningen op de Zuiderhelft van Bonaire, Amigoe di Curaffao 25.II.I944. - Figures of petrographs from Bonaire: Pos Calbas.

1947 Westerman, J. H.: Natuurbescherming op de Nederlandse Antillen ... W.I. Gids 28, p. 193-216. - Plate I fig. 2-3 from Wagenaar Hummelinck, 1938.

1948 Officieel gedenkboek ... Oranje en de zes Caraïbische parelen. Amsterdam. - Fig. 6(d) (e), as before.

1949 Oranje en de zes Caraibische parelen. Orange and the six Caribbean pearls. Platenboek/Picturebook. - As before.

1950 Poll, Willem van DE: De Nederlandse Antillen. Een fotoreportage van land en volk. 's Gravenhage. - Photograph of petrographs from Bonaire: Spelonk. (p. (169))

1951 Hartog, John: Indians in old-time Aruba. Aruba Esso News 2 I Dec. I95I, p. 5, 3 figg. - Photograph of petrographs from Aruba: Piedra Plat; repr. of drawings by Martin, 1888.

1952 Walterus, Fr. M.: Nos Tera I, De Nederlandse Antillen. Curaçao. - Photograph of petrographs from Bonaire: Spelonk. (p. 93) - 2nd Ed. 1953.

\section{S U M M A R Y}

\section{LINEAR ROCK DESIGNS OF CURAÇAO, ARUBA AND BONAIRE}

The archeological investigation.

During the years 1870-1886 Father A. J. van KoolwiJk (1881, 1882, 1885 ) - who is looked upon as the pioneer of the archeological investigation of the Netherlands Antilles - collected a great many antiquities which fairly soon after they had come into possession of the National Museum of Antiquities in Leiden, were studied by C. LeEmans and others $(1880,1904)$. Great value was attached to van KoolwiJ K's finds as also 
appears from the publication by Mr. J. P. B. DE Josselin DE JoNG in 1918. His publications of 1920 and 1923 represented at the same time the last contributions to the archeological knowledge of the Dutch islands of the Leeward Group.

To the members of the Netherlands Antilles Natural Science Study Group, the linear rock designs, shell heaps and potsherds were far too conspicuous things for them to be neglected. One of the members, $\mathrm{Mr}$. A. D. Ringma, in particular, felt very much drawn to archeological work. With that object he made many excursions from March 1949 till June 1951; at first often together with the author of this review, sometimes accompanied by other members of the Study Group, but mostly alone.

In Curaçao - of which island no designs were known yet - linear rock designs (in this paper called petrographs) were found in several places, in one place even rock engravings (in this paper called petroglyphs) were encountered. Rubbish heaps and skeletons were met with, and potsherds were collected. Also the island of Aruba was investigated but not thoroughly enough to get a satisfactory survey of the many in teresting things to be found in this island. Neither could Bonaire be given the attention this island really deserved.

For that reason it was decided to postpone the description of the numerous petrographs from the cave of Fontein in Aruba and the well-known findspots of Onima and Spelonk in Bonaire, till sufficient material is available.

Mr. Ringma has aimed at a stock-taking of the petrographs in the localities which were visited by him. His rough drafts - supplemented with some of the author's as regards some finds-pots which RINGma did not visit - form the basis of this article. As in many cases it turned out to be difficult to obtain an objective picture of that which had remained of the rock-drawings, some of the author's sketches have been inserted which have partly been touched up from photographs, finally there are a couple of photographs themselves.

We hope that the material offered here without commentary will tell us something of the former, little known, inhabitants of these small islands off the South American mainland coast.

What we do know of the rock-drawings.

In 1836 the Rev. G. B. Bosch devoted some observations to the many petrographs in the limestone cave of Fontein in Aruba. VAN KoolwIJK (1882) was already acquainted with 27 places showing figures on limestone and diorite blocks in Aruba; most of them had been put on with red colouring matter, some with white, and only one with black (1885).

In 1885 Professor Martin published for the first time a series of pictures from the cave of Fontein and of the Seroe Canashito (fig. 3, 26).

Alphonse Pinart discussed the Aruba designs in an essay of 1890 (which the present author has not been able to lay his hands on) and which was summarized by Mallery (1893).

Father EUwens published a series of sketches in 1907, which vaN KoolwIJK, in 1875, made of the rock-drawings on the north coast of Bonaire (fig. 4). The latest important find was made in 1944 by Father BRENNEKER in South Bonaire (fig. 34). 
DESCRIPTION OF THE LOCALITIES.

Curaçao (C 1-10)

At the northern border of the Tafelberg (Table Mountain) (C 1, fig. $6,9,16,17)$ we still find a couple of faded petrographs put on with a brownish red pigment, on a limestone wall some tens of meters high. Conspicuous are the large masses of shells of eatable molluscs here piled up at a height of about 150 meters.

In several places on the edge of a limestone terrace along the North Coast (cf. fig. 1) rests of brownish red petrographs are encountered. Those of $\mathrm{C} 2$ are found at the entrance of a cave. C 3 is a surf notch with only vague remainders. In the narrow rock-shelter of $\mathrm{C} 4$ only one figure can be seen clearly. An old shelter with rubbish heap, C 5, showed nothing but smears, with close near it, C 5, one design on an exposed part. The petrographs of C 7-9 are found in narrow surf notches. On Curaçao the most distinct series of designs so far were found near the Serie di Cueba, C 10.

Special mention should be made of some indistinct figures cut in coarse coral limestone on the north coast near Hato (C 4, fig. 20, 21) which seem to be not only very old and weatherworn, but moreover give the impression of not having been made by those who are held responsible for the brownish red designs. It is remarkable that intricate figures were cut in a place that would at present hardly be chosen for inscriptions, unless from absolute necessity.

\section{Aruba (A 2-5)}

In the surroundings of Santa Cruz heaps of large boulders of diorite are scattered over the level landscape (cf. fig. 2). Many of them show big round cavities, mostly in the southwestern side, which must have served as shelters to former inhabitants. In one of these shelters (A 2) a large part of the wall has been painted with whitish and brownish figures while in some places it can be observed how the red has been painted on the white. In touching the wall these figures may easily be damaged and even be lost, which in recent times has probably often occurred. In another place (A 3) some reddish-brown figures are met with which are also damaged because the wall has flaked off.

On the north side of the Seroe Canashito there are two small limestone caves (A 4 and A 5) containing a great number of remarkable but partly indistinct figures. They must have been known to Father van KooLwIJK. The series of sketches of the Canashito published by Prof. Martin are designs from the cave (C 4) that is now threatened with destruction by a quarry.

Bonaire (B 5 and 7)

Close to the well-known (though not treated here) find-spots of the Seroe Plat, near Onima, we find, near Fontein (B 5), on a tumbled-down limestone block, sorhe brownish-red signs.

A larger series of reddish-brown marks are met with near a well, called Pos Calbas (B 7), in the low limestone plain of South Bonaire. 